\title{
Chromophore-labelled, luminescent platinum complexes: syntheses, structures, and spectroscopic properties
}

\author{
Oliver J. Stacey, ${ }^{a}$ Benjamin D. Ward, ${ }^{a}$ Simon J. Coles, ${ }^{b}$ Peter N. Horton ${ }^{b}$ and Simon J. A. Pope ${ }^{a} *$ \\ Received (in XXX, XXX) Xth XXXXXXXXX 20XX, Accepted Xth XXXXXXXXX 20XX \\ DOI: 10.1039/b000000x
}

Ligands based upon 4-carboxamide-2-phenylquinoline derivatives have been synthesised with solubilising octyl hydrocarbon chains and tethered aromatic chromophores to give naphthyl $\left(\mathbf{H L}^{2}\right)$, anthracenyl $\left(\mathbf{H L}^{3}\right)$ and pyrenyl $\left(\mathbf{H L}^{\mathbf{4}}\right)$ ligand variants, together with a non-chromophoric analogue $\left(\mathbf{H L}^{\mathbf{1}}\right)$ for comparison. ${ }^{1} \mathrm{H}$ NMR spectroscopic studies of the ligands showed that two non-interchangeable 10 isomers exist for $\mathbf{H L}^{2}$ and $\mathbf{H L}^{4}$ while only one exists for $\mathbf{H L}^{1}$ and $\mathbf{H L}^{3}$. Supporting DFT calculations on $\mathrm{HL}^{4}$ suggest that the two isomers may be closely isoenergetic with a relatively high barrier to exchange of ca. $100 \mathrm{kJmol}^{-1}$. These new ligands were cyclometalated with $\mathrm{Pt}(\mathrm{II})$ to give complexes $\left[\mathrm{Pt}\left(\mathbf{L}^{1-4}\right)(\mathrm{acac})\right]$ $($ acac $=$ acetylacetonate $)$. The spectroscopically characterised complexes were studied using multinuclear NMR spectroscopy including ${ }^{195} \mathrm{Pt}\left\{{ }^{1} \mathrm{H}\right\}$ NMR studies which revealed $\delta_{\mathrm{Pt}} c a .-2785 \mathrm{ppm}$ for $\left[\mathrm{Pt}\left(\mathbf{L}^{\mathbf{1 -}}\right.\right.$

$\left.\left.{ }_{15}{ }^{4}\right)(\mathrm{acac})\right]$. X-ray crystallographic studies were undertaken on $\left[\mathrm{Pt}\left(\mathbf{L}^{3}\right)(\mathrm{acac})\right]$ and $\left[\mathrm{Pt}\left(\mathbf{L}^{4}\right)(\mathrm{acac})\right]$, each showing the weakly distorted square planar geometry at $\operatorname{Pt}(\mathrm{II})$; the structure of $\left[\operatorname{Pt}\left(\mathbf{L}^{3}\right)\right.$ (acac) $]$ showed evidence for intermolecular Pt-Pt interactions. The UV-vis. absorption studies show that the spectral profiles for $\left[\mathrm{Pt}\left(\mathbf{L}^{2-4}\right)(\mathrm{acac})\right]$ are a composite of the organic chromophore centred bands and a broad ${ }^{1} \operatorname{MLCT}\left(5 d \rightarrow \pi^{*}\right)$ band $(c a .440 \mathrm{~nm})$ associated with the complex. Luminescence studies showed that ${ }_{20}$ complexes $\left[\mathrm{Pt}\left(\mathbf{L}^{2-4}\right)(\mathrm{acac})\right]$ are dual emissive with fluorescence characteristic of the tethered fluorophore and long-lived phosphorescence attributed to ${ }^{3} \mathrm{MLCT}$ emission. In the case of the pyrenyl derivative, $\left[\mathrm{Pt}\left(\mathbf{L}^{4}\right)(\mathrm{acac})\right]$, the close energetic matching of the ${ }^{3} \mathrm{MLCT}$ and ${ }^{3} \mathrm{LC}_{\mathrm{pyr}}$ excited states led to an elongation of the ${ }^{3}$ MLCT emission lifetime ( $\tau=42 \mu$ s) under degassed solvent conditions, suggestive of energy transfer processes between the two states.

\section{${ }_{25}$ Introduction}

Chromophore-appended, luminescent transition metal complexes have enjoyed significant attention over the years due to the wide variety of both fundamental and applied studies that are possible with such systems. ${ }^{1}$ The interactions of photoactive units, be they 30 covalently linked in simple dyad systems or self-assembled into supramolecular architectures, can allow studies into electron ${ }^{2}$ and energy transfer ${ }^{3}$ mechanisms, triplet-triplet annihilation and upconversion. ${ }^{4}$ The interplay between chromophore-localized and complex-based excited states has been commonly studied with a ${ }_{35}$ range of $d^{6}$ and $d^{8}$ heavy metal transition metals including, most commonly, Ru(II).

The use of pyrene as a photoactive unit in such systems has also attracted particular attention. Highly structured monomertype fluorescence at $320-400 \mathrm{~nm}$, an unstructured broad excimer-

40 type emission at $430-460 \mathrm{~nm}$ and long-lived phosphorescence at around $600 \mathrm{~nm}$ dominate the emission properties of pyrene and have led to wide applications, particularly in sensing. ${ }^{5}$ A large number of studies have investigated the photophysical properties of luminescent complexes that incorporate pyrene 45 chromophore(s) into the ligand architecture; a recent article has reviewed metal-pyrene assemblies and their photophysical properties. $^{6}$

Some reports have also focused on pyrene-derived ligands as cyclometalating components within $\mathrm{Ir}(\mathrm{III})^{7}$ and $\mathrm{Pt}(\mathrm{II})$ complexes, ${ }^{8}$ ${ }_{50}$ leading to the heavy metal mediated population of ligand-centred triplet states. Such species have been shown to possess a range of luminescent properties and can also display highly efficient singlet oxygen $\left({ }^{1} \mathrm{O}_{2}\right)$ photogeneration. ${ }^{9}$

Of relevance to this paper are the reports of complexes that 55 incorporate tethered chromophores via a linking (or spacer) bridge, and complexes that show extended luminescent lifetimes due to the energy reservoir effect, arising through thermal equilibration between triplet metal-to-ligand charge transfer $\left({ }^{3} \mathrm{MLCT}\right)$ and triplet ligand-centred pyrene $\left({ }^{3} \mathrm{LC}_{\mathrm{pyr}}\right)$ excited ${ }_{60}$ states. ${ }^{10}$ The requirement for this reversible triplet-triplet energy transfer is that the two excited states must lie in close energetic proximity, the observable manifestation of which leads to elongated ${ }^{3}$ MLCT lifetimes. Pyrene-appended diimine complexes of $\mathrm{Ru}(\mathrm{II})$ are the classical examples in this context: the ${ }^{3} \mathrm{MLCT}$ ${ }_{65}$ lifetime of the $\left[\mathrm{Ru}(\mathrm{bpy})_{3}\right]^{2+}$ chromophore can be extended well into the microsecond domain by excited state equilibration with long-lived ${ }^{3} \mathrm{LC}_{\mathrm{pyr}}$ where the energetic difference in the states is ca. $600 \mathrm{~cm}^{-1} \cdot{ }^{11}$ Although $\mathrm{Ru}(\mathrm{II})$ diimine systems represent the vast majority of the reported examples that show elongated 
${ }^{3}$ MLCT lifetimes via this mechanism, a few studies have also looked at cyclometalated $\operatorname{Ir}(\mathrm{III})$ species which also show remarkable extension of lifetimes and high sensitivity to dissolved ${ }^{3} \mathrm{O}_{2}{ }^{12}$

5 The majority of $\mathrm{Pt}(\mathrm{II})$ complexes that incorporate a pyrene moiety into the ligand fragment show ${ }^{3} \mathrm{LC}_{\mathrm{pyr}}$ based phosphorescence because this triplet state often lies below any ${ }^{3}$ MLCT state associated with the $\mathrm{Pt}(\mathrm{II})$-based chromophore. Acetylide complexes of $\mathrm{Pt}(\mathrm{II})$ which possess conjugated pyrene 10 units are a typical example where the long-lived, room temperature emission can be solely attributed to ${ }^{3} \mathrm{LC}_{\mathrm{pyr}} \cdot{ }^{13}$ The group of McMillin has reported cyclometalated Pt(II) complexes that incorporate a 4-substituted $2,2^{\prime}: 6^{\prime}, 2^{\prime \prime}$-terpyridine (trpy) ligand wherein the conjugated, pyrene-appended complex shows a long

15 lifetime of $45 \mu \mathrm{s}$ in fluid solution. However, this lifetime was not attributed to energy reservoir effects, but rather the predominance of ${ }^{3} \mathrm{LC}_{\mathrm{pyr}}$ character to the emitting state. ${ }^{14}$ In earlier work the same group reported a similar trpy-pyrene Pt(II) compound and attributed the long luminescent lifetime of the complex to an ${ }_{20}$ excited state of mixed ${ }^{3} \mathrm{ILCT} /{ }^{3} \mathrm{LC}_{\mathrm{pyr}} /{ }^{3} \mathrm{MLCT}$ parentage, although the possibility of excited state equilibrium between the ${ }^{3}$ ILCT and ${ }^{3} \mathrm{LC}_{\mathrm{pyr}}$ states, by anology with earlier discussion, could not be ruled out. ${ }^{15}$ Zhao and Guo have reported Schiff base complexes of $\mathrm{Pt}(\mathrm{II})$ that include conjugated pyrene chromophores and one of 25 these complexes possesses luminescent properties that appear to be consistent with a ${ }^{3} \mathrm{MLCT} /{ }^{3} \mathrm{LC}_{\mathrm{pyr}}$ thermal equilibration giving extended lifetimes in the microsecond domain. ${ }^{16}$

To the best of our knowledge all of the pyrene-platinum dyads reported thus far all involve direct conjugation of the pyrene unit 30 to the chelating ligand and/or direct coordination to the platinum centre. We therefore report the first series of functionalised cyclometalated $\mathrm{Pt}(\mathrm{II})$ complexes, $\left[\mathrm{Pt}\left(\mathbf{L}^{\mathbf{n}}\right)(\mathrm{acac})\right]$ based upon a substituted 4-carboxamido-2-phenylquinoline ligand, that incorporate a tethered chromophore (naphthyl, anthracenyl and 35 pyrenyl) and builds on our prior work on cyclometalated luminescent $\mathrm{Pt}(\mathrm{II})$ species that encompass the 4-substituted, 2phenylquinoline moiety. ${ }^{17}$ Crucially in such complexes the emitting state of the $\mathrm{Pt}(\mathrm{II})$ complexes is primarily ${ }^{3} \mathrm{MLCT}$ in character with a tuneable emission wavelength around 610-630 ${ }_{40} \mathrm{~nm}\left(c f\left[\mathrm{Ru}(\mathrm{bpy})_{3}\right]\left(\mathrm{PF}_{6}\right)_{2}\right.$ emits at $615 \mathrm{~nm}^{18}$ in $\left.\mathrm{MeCN}\right)$. Therefore such species should be viable candidates for probing energy reservoir effects with selected chromophores such as pyrene. In this study, the complexes are further adorned with a lipophilic octyl hydrocarbon chain to enhance the solubility properties of 45 the ligand precursors and enable study of the Pt(II) coordination chemistry. This paper discusses the synthetic routes, characterisation, including X-ray crystal structures, and luminescence properties of these new ligands and complexes.

50

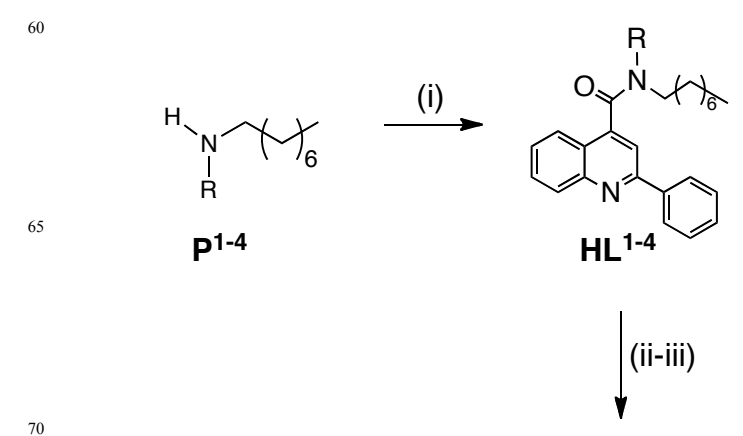

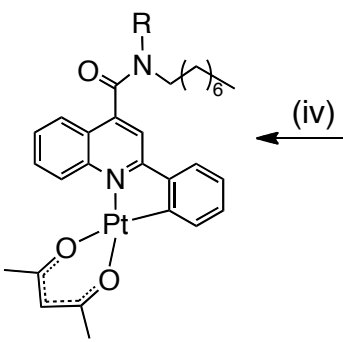

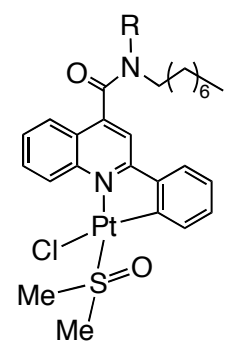

$\left[\mathrm{Pt}\left(\mathrm{L}^{1-4}\right)(\right.$ acac $\left.)\right] \quad\left[\mathrm{Pt}\left(\mathrm{L}^{1-4}\right)(\mathrm{DMSO}) \mathrm{Cl}\right]$

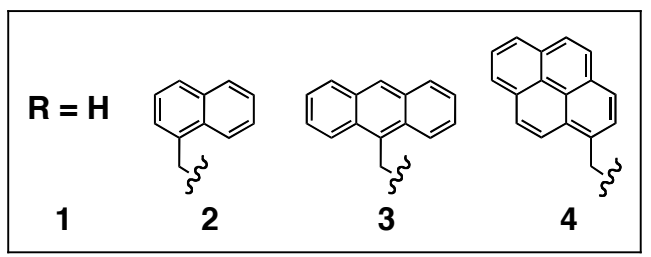

Scheme 1. Synthetic route to the ligands and platinum complexes. (i) 2phenylquinoline-4-carbonyl chloride, $\mathrm{CHCl}_{3}$; (ii) $\mathrm{K}_{2} \mathrm{PtCl}_{4}, \mathrm{H}_{2} \mathrm{O}$,

$85 \mathrm{EtO}\left(\mathrm{CH}_{2}\right)_{2} \mathrm{OH}$; (iii) DMSO; (iv) sodium acetylacetonate, 3-pentanone.

\section{Results and Discussion}

\section{Synthesis and characterisation of the ligands}

Initially syntheses of chromophoric ligands lacking the alkyl 90 chain were attempted via condensation of different chromophoric amino precursors (e.g. 1-aminonaphthalene, 1aminomethylpyrene) with 2-phenylquinoline-4-carbonyl chloride. However, the resultant prospective ligands were found to be insoluble in all common solvents other than DMSO and ${ }_{95}$ subsequent attempts to synthesise the corresponding Pt(II) dimers were unsuccessful using established methodologies. To overcome the limiting solubility of these species an alternative target was sought that incorporated an alkyl chain into the ligand architecture (Scheme 1). Thus, the precursor secondary amines $100\left(\mathbf{P}^{2-4}\right)$ were formed from the reductive amination of 1-octylamine $\left(\mathbf{P}^{1}\right)$ with the aryl aldehyde of the corresponding chromophore (1naphthaldehyde, 9-anthracenecarboxaldehyde, 1pyrenecarboxaldehyde). $\quad \mathbf{P}^{2-4}$ were then reacted with 2phenylquinoline-4-carbonyl chloride to form the corresponding 105 ligands $\mathbf{H L}^{2-4}$ in good yields. The chromophore-free analogue $\mathbf{H L}^{1}$ was synthesised by condensing 1-octylamine with 2 phenylquinoline-4-carbonyl chloride and has been reported 
previously. ${ }^{17 \mathrm{~b}}$

Characterisation of these new ligands was achieved using a variety of standard techniques. In the ${ }^{1} \mathrm{H}$ NMR spectra of the ligands a number of identifying features were observed. Upon 5 comparison with the data for $\mathbf{H L}^{\mathbf{1}}$, for $\mathbf{H L}^{3}$ the methylene group linking the anthracenyl unit to the amide group appeared as a set of diastereotopic signals centred $c a$. 6.05 ppm (with a geminal coupling constant of ${ }^{2} J_{\mathrm{HH}}=15.2 \mathrm{~Hz}$ ), suggesting a rigid conformation of a single isomer with limited rotation of the 10 anthracenyl moiety. In the corresponding spectra of $\mathbf{H L}^{\mathbf{2}}$ and $\mathbf{H L}^{4}$, the same methylene group revealed two distinct sets (SI, Fig. S1) of diastereotopic protons (in an approximate 2:1 ratio), suggesting that there were two distinct isomeric forms of these ligands, attributed to restricted rotation about the amide bond.

${ }_{15}$ The major isomer displayed two distinct doublets with a geminal coupling constant ${ }^{2} J_{\mathrm{HH}} \sim 15 \mathrm{~Hz}$, the minor isomer a much broader, less resolved signal. The presence of two isomers in $\mathbf{H L}^{2}$ and $\mathbf{H L}^{4}$ leads to a highly complex set of overlapping aromatic signals. In our hands these isomers were found to be inseparable 20 using column chromatography.

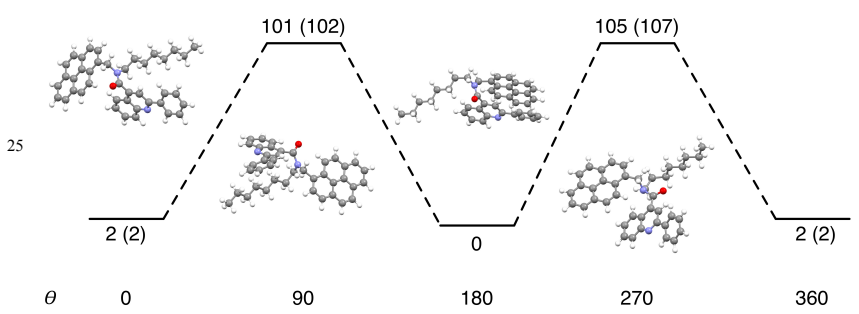

30

Figure 1. Calculated relative enthalpies (free energies in $\mathrm{kJmol}^{-1}$ ) of ligand $\mathbf{H L}^{4}$ as a function of the dihedral angle $\theta\left(\mathrm{O}-\mathrm{C}-\mathrm{N}-\mathrm{C}_{\mathrm{pyrene}}\right)$.

\section{Conformational analysis of the isomeric forms of $\mathrm{HL}^{4}$}

${ }_{35}$ Since the ligand contains an amide linkage, there is a possibility of significant delocalization of the $\pi_{(\mathrm{C}=\mathrm{O})}$ and $\mathrm{N}_{\pi}$ orbitals; disruption of this delocalization is therefore expected to give rise to restricted rotation about the amide bond. The presence of an unsymmetrical quinoline amide substituent means that the two in${ }_{40}$ plane amide orientations correspond to two different isomeric forms. We probed the energetics by which these two isomers could interconvert using computational methods. A relaxed potential energy surface scan, obtained by systematically varying the amide $\mathrm{O}-\mathrm{C}-\mathrm{N}-\mathrm{C}_{\text {pyrene }}$ dihedral angle, whilst allowing the ${ }_{45}$ remaining centers to optimize, afforded an energy profile similar to that displayed in Fig. x. As expected, the energy profile shows two minima, corresponding to approximate dihedral angles of $0{ }^{\circ}$ and $180^{\circ}$, i.e. structures in which the $\mathrm{N}_{\pi}$ lone pair can be considered delocalized over the amide group. In addition, the 50 energy profile contains two maxima, corresponding to the two perpendicular arrangements of the amide group, in which the $\pi_{(\mathrm{C}=\mathrm{O})}$ and $\mathrm{N}_{\pi}$ orbitals are orthogonal.

Taking structures along the calculated potential energy surface as suitable starting points, the minima and transition state ${ }_{55}$ structures were optimized without geometry restraints, and their relative energies obtained (Fig. 1). As expected, the two minima correspond to structures in which the $\mathrm{O}-\mathrm{C}-\mathrm{N}-\mathrm{C}_{\text {pyrene }}$ dihedral angles are approximately $0^{\circ}$ and $180^{\circ}$ (optimized values are $-1^{\circ}$ and $175^{\circ}$ respectively), consistent with qualitative predictions. ${ }_{60}$ Likewise, the two transition states were found to have dihedral angles of $103^{\circ}$ and $293^{\circ}$, somewhat distorted from an ideal $90^{\circ}$ and $270^{\circ}$ (based upon a pure delocalization argument), which presumably lies in the fact that the sterics of the peripheral amide groups have an effect on the precise position of the maxima on ${ }_{65}$ the potential energy surface. Interestingly, the ground state structure with a dihedral of $c a$. $180^{\circ}$ was found to be highly dependent on the method used in the calculations. This particular conformation brings the pyrene and quinoline rings into close proximity; the structures reported herein exhibit an angle between 70 the two planes of $13^{\circ}$, whereas calculations performed without considering dispersion effects gave an analogous structure with an angle of $73^{\circ}$. Whilst the relative energies of the two ground state structures was largely unaffected (within typical error limits assigned to DFT calculations), this observation nevertheless

75 highlights the potential impact of dispersion effects on structural prediction and interpretation. ${ }^{19}$

The two ground state isomers are calculated to be within 2 $\mathrm{kJ} \mathrm{mol}^{-1}$, which is essentially isoenergetic within typical DFT error limits. This is entirely consistent with the isomers being 80 present in approximately equal concentrations, as determined by NMR spectroscopy. Moreover, the calculated activation barriers for interconversion of the isomers give $\Delta \mathrm{G}=102$ and $107 \mathrm{~kJ} \mathrm{~mol}^{-}$ 1 , which are relatively high; given that no interconversion was detected by NMR spectroscopy at room temperature, these ${ }_{85}$ calculated activation energies are consistent with the experimental observations. These results can be favourably compared to a study in which the rotation of an $\mathrm{N}$-aryl bond was investigated. $^{20}$ The activation barrier was found to be $c a .77$ $\mathrm{kJ} . \mathrm{mol}^{-1}$, and rotation of the aryl group was observed only upon 90 heating to $\geq 70{ }^{\circ} \mathrm{C}$; given that no such interchange was observed for the system described here, the calculated values are plausible and support the experimental data. Coordinates for the calculated structures are provided in the ESI.

\section{Synthesis and characterization of cyclometalated Pt(II) ${ }_{95}$ complexes}

The target complexes $\left[\operatorname{Pt}\left(\mathbf{L}^{1-4}\right)(\mathrm{acac})\right]$ were synthesised in two steps from $\mathrm{K}_{2} \mathrm{PtCl}_{4}$ via the precursor $\left[(\mathbf{L}) \mathrm{Pt}-\mu-\mathrm{Cl}_{2} \mathrm{Pt}(\mathbf{L})\right]$ dimer (obtained via dropwise addition of $\mathrm{K}_{2} \mathrm{PtCl}_{4}$ in water to the ligand in 2-ethoxyethanol). ${ }^{21}$ The resultant dimers were split by $100 \mathrm{DMSO}^{22}$ to give the intermediate monometallic DMSO adduct $[\mathrm{Pt}(\mathbf{L})(\mathrm{DMSO}) \mathrm{Cl}]$ which was then reacted with sodium acetylacetonate to give $\left[\mathrm{Pt}\left(\mathbf{L}^{1-4}\right)(\mathrm{acac})\right]$.

For $\left[\operatorname{Pt}\left(\mathbf{L}^{3}\right)(\mathrm{acac})\right],{ }^{1} \mathrm{H}$ NMR spectroscopy showed (SI, Fig. S2) a single isomer consistent with the $\mathbf{H L}^{3}$ data, with a single set of 105 proton resonances associated with the coordinated $\beta$-diketonate ligand (one bridging $\mathrm{CH}$ resonance $\mathrm{ca} .5 .5 \mathrm{ppm}$, and two unique methyl resonances $c a$. $2 \mathrm{ppm}$ due to the unsymmetrical nature of the Pt coordination sphere) and the diastereotopic methylene protons again at $5.5-6.5 \mathrm{ppm}$. In comparison $\left[\mathrm{Pt}\left(\mathbf{L}^{2}\right)(\mathrm{acac})\right]$ and $110\left[\operatorname{Pt}\left(\mathbf{L}^{4}\right)(\mathrm{acac})\right]$ revealed more complex ${ }^{1} \mathrm{H}$ NMR spectra, with the presence of two isomers giving overlapping aromatic resonances due to doubling of the signals. For these speices, the aliphatic region was more informative, as indicated via resonances of the coordinated $\beta$-diketonate ligand (two singlets at $c a .5 .5 \mathrm{ppm}$ that 115 correspond to the bridging $\mathrm{CH}$, and four singlets around $2 \mathrm{ppm}$ 
assigned to the methyl groups), and the two sets of diastereotopic protons for the methylene group at 4.5-6.5 ppm that are subtly shifted from the free ligands. Variable temperature NMR spectroscopy revealed no interchange of the isomers at elevated 5 temperatures (up to $90^{\circ} \mathrm{C}$ in $\mathrm{d}_{8}$-toluene), which correlates with the high activation barrier for isomerisation predicted by the computational studies on $\mathbf{H L}^{4}$. The downfield region of the ${ }^{13} \mathrm{C}\left\{{ }^{1} \mathrm{H}\right\}$ NMR spectra (SI, Figs S3 and S4) for the complexes was also informative revealing two resonances $>180 \mathrm{ppm}$ for the 10 coordinated acac ligand in both $\left[\operatorname{Pt}\left(\mathbf{L}^{1}\right)(\mathrm{acac})\right]$ and $\left[\operatorname{Pt}\left(\mathbf{L}^{3}\right)(\mathrm{acac})\right]$, but four resonances for $\left[\operatorname{Pt}\left(\mathbf{L}^{2}\right)(\mathrm{acac})\right]$ and $\left[\operatorname{Pt}\left(\mathbf{L}^{4}\right)(\right.$ acac $\left.)\right]$, again consistent with the presence of two isomeric forms in the latter complexes. The large number of unique aromatic resonances in $\left[\operatorname{Pt}\left(\mathbf{L}^{\mathbf{3}}\right)(\mathrm{acac})\right]$ (SI, Fig S4) was anticipated for a rigid ligand 15 system with restricted rotation about the amide functional group.

The ${ }^{195} \mathrm{Pt}\left\{{ }^{1} \mathrm{H}\right\}$ NMR spectra (for example, SI, Fig S5) for the complexes revealed little variation according to ligand type with broad resonances of $\delta_{\mathrm{Pt}} \quad-2776 \quad\left[\mathrm{Pt}\left(\mathbf{L}^{\mathbf{1}}\right)(\mathrm{acac})\right], \quad-2784$ $\left[\operatorname{Pt}\left(\mathbf{L}^{2}\right)(\mathrm{acac})\right],-2786\left[\operatorname{Pt}\left(\mathbf{L}^{3}\right)(\mathrm{acac})\right]$ and $-2788 \mathrm{ppm}\left[\operatorname{Pt}\left(\mathbf{L}^{4}\right)(\mathrm{acac})\right]$ 20 which are consistent with our previous data on cyclometalated $\mathrm{Pt}(\mathrm{II})$ complexes ${ }^{17}$ that incorporate the 2-phenylquinoline chelate, as well as comparable with the value of $\delta_{\mathrm{Pt}}-2868 \mathrm{ppm}$ for $[\operatorname{Pt}($ ppy $)(\mathrm{acac})]$ (where ppy $=$ 2-phenylquinoline). ${ }^{23}$ The similarities in the values suggest that the donating ability of the 25 cyclometalating ligand essentially remains unchanged by the variation in the chromophoric component of the ligand backbone.

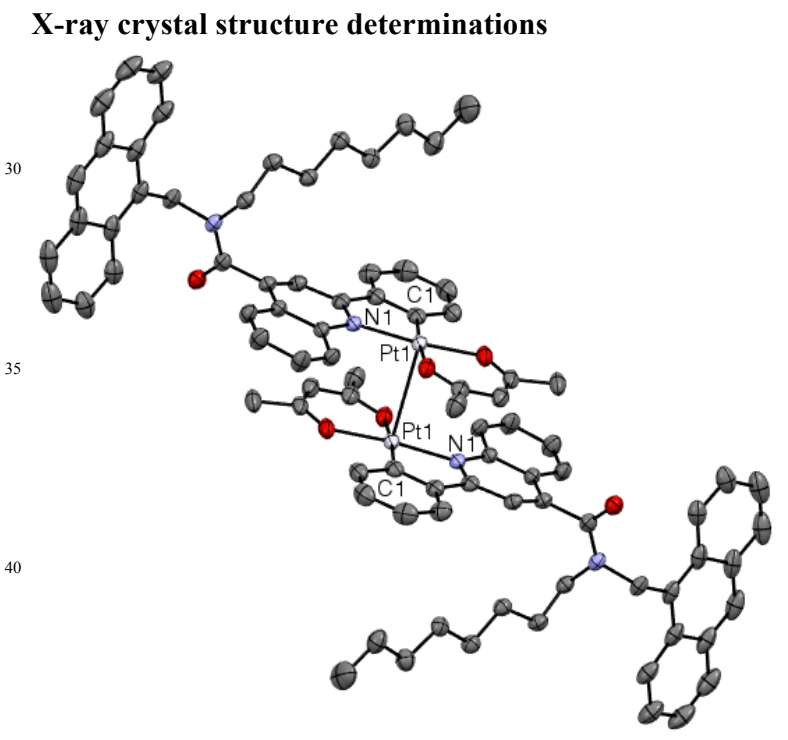

Figure 2. X-ray crystal structure of $\left[\operatorname{Pt}\left(\mathbf{L}^{3}\right)(\mathrm{acac})\right]$. Hydrogen atoms are omitted for clarity and ellipsoids are drawn at $50 \%$ probability.

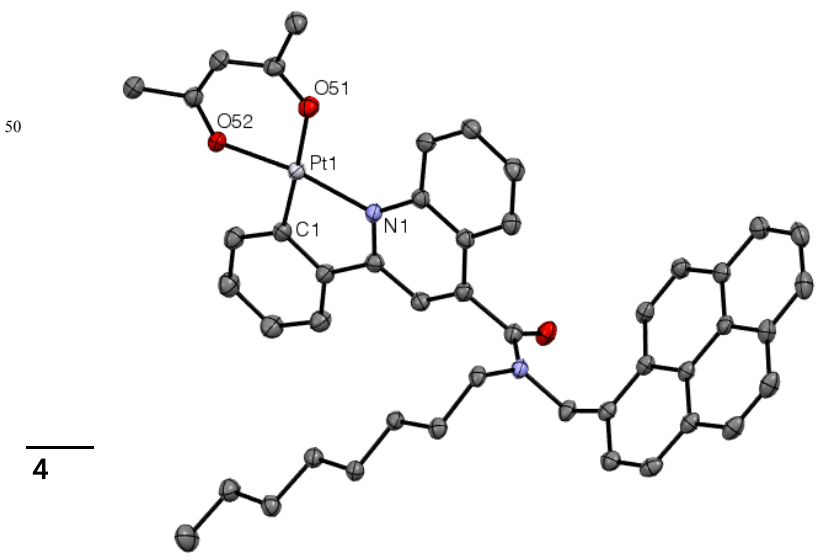

55

\begin{tabular}{|c|c|c|}
\hline Crystal & {$\left[\mathrm{Pt}\left(\mathrm{L}^{3}\right)(\mathrm{acac})\right]$} & {$\left[\operatorname{Pt}\left(\mathrm{L}^{4}\right)(\mathrm{acac})\right]$} \\
\hline Empirical Formula & $\mathrm{C}_{44} \mathrm{H}_{44} \mathrm{~N}_{2} \mathrm{O}_{3} \mathrm{Pt}$ & $\mathrm{C}_{49.5} \mathrm{H}_{48} \mathrm{~N}_{2} \mathrm{O}_{3} \mathrm{Pt}$ \\
\hline Formula wt $/ \mathrm{g} \mathrm{mol}^{-1}$ & 843.90 & 913.99 \\
\hline $\begin{array}{l}\text { Crystal System, } \\
\text { space group }\end{array}$ & $\begin{array}{l}\text { Monoclinic, } \\
\qquad P 2_{1} / c\end{array}$ & $\begin{array}{c}\text { Triclinic, } \\
P-1\end{array}$ \\
\hline $\mathrm{a} / \AA$ & $17.5181(11)$ & $8.9153(5)$ \\
\hline $\mathrm{b} / \AA \AA$ & $14.2716(10)$ & $12.6111(9)$ \\
\hline $\mathrm{c} / \AA ̊$ & $16.0586(11)$ & $18.5893(13)$ \\
\hline$\alpha /{ }^{\circ}$ & 90 & $77.279(3)$ \\
\hline$\beta /{ }^{\circ}$ & $117.1440(5)$ & $83.655(3)$ \\
\hline$\gamma /{ }^{\circ}$ & 90 & $76.145(3)$ \\
\hline $\mathrm{Vol} / \AA^{3}$ & $3572.6(4)$ & $1975.7(2)$ \\
\hline $\begin{array}{l}\mathrm{Z}, \text { Calc density } \\
\left(\mathrm{Mgm}^{-3}\right)\end{array}$ & $4,1.569$ & $2,1.536$ \\
\hline $\operatorname{Abs}$ coeff $\left(\mathrm{mm}^{-1}\right)$ & 3.971 & 3.597 \\
\hline $\mathrm{F}(000)$ & 1696 & 922 \\
\hline Crystal & Red plate & Orange plate \\
\hline $\begin{array}{l}\text { Crystal Dimensions/ } \\
\mathrm{mm}^{3}\end{array}$ & $\begin{array}{c}0.09 \times 0.06 \times \\
0.01\end{array}$ & $\begin{array}{c}0.24 \times 0.14 \times \\
0.02\end{array}$ \\
\hline$\theta$ range $\left(^{\circ}\right)$ & $2.613-27.505$ & $2.533-27.521$ \\
\hline $\begin{array}{l}\text { No. of reflections } \\
\text { collected }\end{array}$ & 62763 & 26820 \\
\hline $\mathrm{R}_{\text {int }}$ & 0.0502 & 0.0484 \\
\hline $\begin{array}{l}\text { Max. and min. } \\
\text { transmission }\end{array}$ & 1.000 and 0.819 & 1.000 and 0.642 \\
\hline $\begin{array}{c}\text { No. of data/restraints/ } \\
\text { parameters }\end{array}$ & $8196 / 0 / 454$ & $9045 / 80 / 536$ \\
\hline Goodness-of-fit on $\mathrm{F}^{2}$ & 1.045 & 1.048 \\
\hline $\begin{array}{c}\text { Final } R \text { indices }\left[F^{2}>\right. \\
\left.2 \sigma\left(F^{2}\right)\right]: \mathrm{R}_{1}, \mathrm{wR}_{2}\end{array}$ & $0.0236,0.0592$ & $0.0303,0.0843$ \\
\hline $\begin{array}{c}\mathrm{R} \text { indices (all data) : } \\
\mathrm{R}_{1}, \mathrm{wR}_{2}\end{array}$ & $0.0264,0.0611$ & $0.0313,0.0853$ \\
\hline $\begin{array}{c}\text { Largest diff. peak and } \\
\text { hole/e } \AA^{-3}\end{array}$ & $1.589,-0.578$ & $1.697,-1.339$ \\
\hline
\end{tabular}

Figure 3. X-ray crystal structure of $\left[\operatorname{Pt}\left(\mathbf{L}^{4}\right)(\mathrm{acac})\right]$. Hydrogen atoms are omitted for clarity and ellipsoids are drawn at $50 \%$ probability.

Table 1. Data collection parameters for the X-ray structures.

${ }_{65}$ Crystals suitable for X-ray diffraction studies were isolated by slow evaporation of concentrated $\mathrm{CHCl}_{3}$ solutions of complex. Pleasingly two structures confirmed the proposed formulations for the complexes $\left[\operatorname{Pt}\left(\mathbf{L}^{3}\right)(\mathrm{acac})\right]$ and $\left[\operatorname{Pt}\left(\mathbf{L}^{4}\right)(\mathrm{acac})\right]$. Data collection parameters are shown in Table 1 and selected bond 70 lengths $(\AA)$ and angles $\left({ }^{\circ}\right)$ are in Table 2.

The structure of $\left[\operatorname{Pt}\left(\mathbf{L}^{3}\right)(\mathrm{acac})\right]$ has comparable coordination sphere bond lengths to those reported for $[\mathrm{Pt}(\mathrm{ppy})(\mathrm{acac})]{ }^{24}$ The anthracenyl moiety is almost perpendicular to the plane of the phenylquinoline unit $\left(104.86(8)^{\circ}\right)$, providing organised packing. 75 This head-to-tail arrangement results in both $\pi-\pi$ and Pt-Pt 
interactions, with a formal Pt-Pt bond length of 3.2365(2) $\AA$ in the solid state. This compares to a distance of $c a .3 .7 \AA$ for a PtPt interaction in the reported structure of $[\mathrm{Pt}(\mathrm{ppy})(\mathrm{acac})] .^{33}$

In contrast, the structure of $\left[\operatorname{Pt}\left(\mathbf{L}^{4}\right)(\mathrm{acac})\right]$ revealed an isomer which positions the pyrene unit away from the phenylquinoline. The packing arrangement results in very little $\pi$-stacking 10 interactions between the phenylquinoline units and, somewhat surprisingly, none between the pyrene moieties. However, this could be due to the positioning of the octyl chain, which can be seen lying between the pyrene units. There was no evidence for metallophilic interactions in $\left[\operatorname{Pt}\left(\mathbf{L}^{4}\right)(\mathrm{acac})\right]$, presumably due to the 15 bulk of the ligand preventing such interactions in the crystalline form.

It is noteworthy that, with reference to the DFT calculations on the conformational aspects of $\mathrm{HL}^{4}$, both X-ray structural studies reveal arrangements of the ligand where the chromophore was 20 positioned away from the phenylquinoline unit and is not stacking. In the case of $\left[\mathrm{Pt}\left(\mathrm{L}^{3}\right)(\mathrm{acac})\right]$, supporting spectroscopic data has already shown that the species exists as a single isomer, the precise conformational nature of which has been structurally identified by the X-ray studies above. However, for $\left[\mathrm{Pt}\left(\mathrm{L}^{4}\right)(\mathrm{acac})\right]$ 25 the NMR studies showed that two isomers, as supported by the computational work, co-exist, although only one of these isomers was isolated through crystallisation.

Table 2. Selected bond lengths $(\AA)$ and bond angles $\left(^{\circ}\right)$ from the crystallographic data.

\begin{tabular}{|c|c|c|c|}
\hline \multicolumn{2}{|c|}{$\left[\operatorname{Pt}\left(\mathbf{L}^{3}\right)(\mathrm{acac})\right]$} & \multicolumn{2}{|c|}{$\left[\operatorname{Pt}\left(\mathbf{L}^{4}\right)(\mathrm{acac})\right]$} \\
\hline \multicolumn{4}{|c|}{ Bond lengths $(\AA)$} \\
\hline $\operatorname{Pt}(1)-\mathrm{C}(1)$ & $1.962(3)$ & $\operatorname{Pt}(1)-\mathrm{C}(1)$ & $1.970(3)$ \\
\hline $\mathrm{Pt}(1)-\mathrm{O}(51)$ & $2.0032(17)$ & $\mathrm{Pt}(1)-\mathrm{O}(52)$ & $1.998(2)$ \\
\hline $\mathrm{Pt}(1)-\mathrm{N}(1)$ & $2.0550(18)$ & $\mathrm{Pt}(1)-\mathrm{N}(1)$ & $2.056(3)$ \\
\hline $\mathrm{Pt}(1)-\mathrm{O}(52)$ & $2.1057(18)$ & $\mathrm{Pt}(1)-\mathrm{O}(51)$ & $2.098(2)$ \\
\hline $\operatorname{Pt}(1)-\operatorname{Pt}(1)^{\prime}$ & $3.2365(2)$ & & \\
\hline \multicolumn{4}{|c|}{ Bond angles $\left({ }^{\circ}\right)$} \\
\hline $\mathrm{C}(1)-\mathrm{Pt}(1)-\mathrm{O}(51)$ & $89.21(9)$ & C(1)-Pt(1)-O(52) & $89.44(11)$ \\
\hline $\mathrm{C}(1)-\mathrm{Pt}(1)-\mathrm{N}(1)$ & $80.83(9)$ & $\mathrm{C}(1)-\mathrm{Pt}(1)-\mathrm{N}(1)$ & $81.28(12)$ \\
\hline $\mathrm{O}(51)-\mathrm{Pt}(1)-\mathrm{N}(1)$ & 169.91(8) & $\mathrm{O}(52)-\mathrm{Pt}(1)-\mathrm{N}(1)$ & $170.39(9)$ \\
\hline $\mathrm{C}(1)-\operatorname{Pt}(1)-\mathrm{O}(52)$ & $174.64(8)$ & $\mathrm{C}(1)-\mathrm{Pt}(1)-\mathrm{O}(51)$ & $177.52(9)$ \\
\hline $\mathrm{O}(51)-\mathrm{Pt}(1)-\mathrm{O}(52)$ & $88.17(7)$ & $\mathrm{O}(52)-\mathrm{Pt}(1)-\mathrm{O}(51)$ & $89.07(9)$ \\
\hline $\mathrm{N}(1)-\mathrm{Pt}(1)-\mathrm{O}(52)$ & $101.63(7)$ & $\mathrm{N}(1)-\mathrm{Pt}(1)-\mathrm{O}(51)$ & $100.11(10)$ \\
\hline
\end{tabular}

\section{UV-vis. and luminescence spectroscopy}

The free ligands exhibit absorption bands assigned to the different, and overlapping, ligand-centred (LC) ${ }^{1} \pi \rightarrow \pi^{*}$ transitions of the 2-phenylquinoline and the appended chromophores. For ${ }_{35} \mathbf{H L}^{2}$ the 2-phenylquinoline and naphthyl bands overlap in the range 250-350 $\mathrm{nm}$. For $\mathbf{H L}^{3}$ and $\mathbf{H L}^{4}$ the longer wavelength absorptions of the anthracene and pyrene chromophores were clearly assigned due to the distinctive vibronic character of these bands between 320-400 nm (Fig. 4). For the Pt(II) complexes 40 there was an additional broad band at lower energy ( $c a$. 400-480 $\mathrm{nm})$ assigned to a ${ }^{1} \mathrm{MLCT}\left(5 d \rightarrow \pi^{*}\right)$ transition. Our previous studies have employed TD-DFT to elucidate the nature of the lowest energy absorption of substituted 2-phenylquinoline
$[\mathrm{Pt}(\mathrm{L})(\mathrm{acac})]$ complexes, showing that there is a strong MLCT 45 component (i.e. significant $d$-orbital parentage to the HOMO) to this band (SI, Scheme S1). ${ }^{17}$ Both $\left[\operatorname{Pt}\left(\mathbf{L}^{3}\right)(\mathrm{acac})\right]$ and $\left[\operatorname{Pt}\left(\mathbf{L}^{4}\right)(\mathrm{acac})\right]$ also showed the expected vibronic structure attributed to the anthracene and pyrene chromophores, respectively, the tail of which overlaps with the ${ }^{1}$ MLCT band 50 (Fig. 4). In the luminescence studies, firstly, the free ligands were found to be fluorescent in solution, and in the case of $\mathbf{H L}^{2}-\mathbf{H L}^{4}$ the emission profiles were dominated by the appended fluorophore in each case (for example, see SI, Fig S6). $\mathbf{H L}^{3}$ gave a characteristic structured emission profile associated with the 55 anthracene fluorophore, whilst $\mathbf{H L}^{4}$ revealed two peaks at 395 and $438 \mathrm{~nm}$, which is consistent with an excimer type fluorescence. All lifetimes were $<5$ ns consistent with an emitting state of ${ }^{1} \pi-\pi^{*}$ character.

The luminescence from $\left[\operatorname{Pt}\left(\mathbf{L}^{1}\right)(\right.$ acac $\left.)\right]$, which does not 60 incorporate an additional chromophore, was dominated by a broad, featureless emission maximum at $618 \mathrm{~nm}$ assigned to a ${ }^{3}$ MLCT excited state; the corresponding excitation spectrum was dominated by MLCT bands around $425 \mathrm{~nm}$. The emission character of $\left[\operatorname{Pt}\left(\mathbf{L}^{\mathbf{1}}\right)(\mathrm{acac})\right]$ was sensitive to dissolved oxygen: the ${ }_{65}$ intensity of the ${ }^{3}$ MLCT band increased upon degassing of the solvent, whilst the observed lifetime extended from $380 \mathrm{~ns}$ (aerated) to $3.4 \mu \mathrm{s}$ (degassing). A wide range of luminescent complexes have previously shown varying sensitivity to dissolved oxygen, including a number of cyclometalated $\mathrm{Pt}(\mathrm{II})$ 70 species. $^{9}$

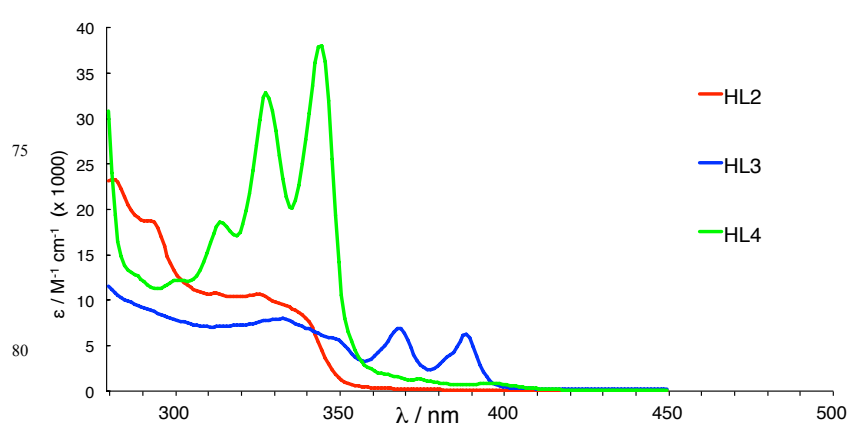

Figure 4. UV-vis. absorption spectra for selected ligands $\left(\mathrm{CHCl}_{3}\right)$.

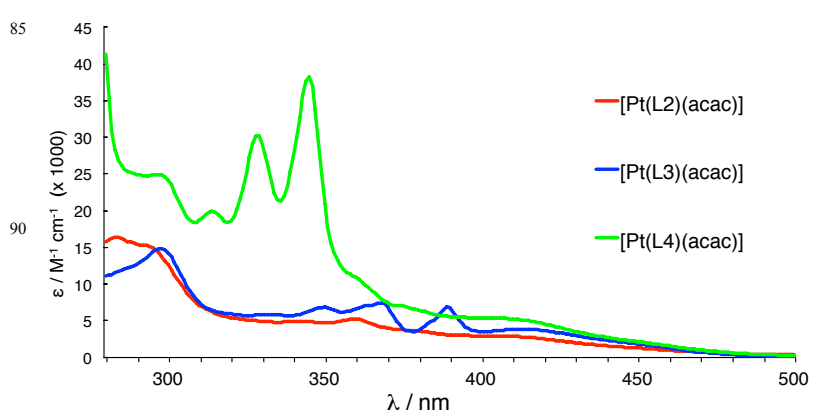

95

Figure 5. UV-vis. absorption spectra for selected Pt(II) complexes $\left(\mathrm{CHCl}_{3}\right)$.

In contrast to $\left[\operatorname{Pt}\left(\mathbf{L}^{\mathbf{1}}\right)(\mathrm{acac})\right]$, the room temperature emission profiles of the chromophore-appended complexes $\left[\operatorname{Pt}\left(\mathbf{L}^{2-4}\right)(\mathrm{acac})\right]$ 100 in aerated chloroform revealed two main components: (i) a 
chromophore-centred fluorescence $<500 \mathrm{~nm}$; (ii) a broad featureless band at $c a .605 \mathrm{~nm}$ attributed to a metal-based excited state of strong ${ }^{3}$ MLCT character (e.g. Fig. 6). These complexes can therefore be described as dual emissive (Table 3). The ${ }_{5}$ excitation profiles $\left(\lambda_{\mathrm{em}} 605 \mathrm{~nm}\right)$ for $\left[\operatorname{Pt}\left(\mathbf{L}^{2}\right)(\mathrm{acac})\right],\left[\operatorname{Pt}\left(\mathbf{L}^{3}\right)(\mathrm{acac})\right]$ and $\left[\operatorname{Pt}\left(\mathbf{L}^{4}\right)(\right.$ acac $\left.)\right]$ all exhibited the MLCT band common to each complex around $420 \mathrm{~nm}$, as well as bands that could be clearly
The potential interplay of the ${ }^{3} \mathrm{LC}$ states of the appended chromophore (naphthyl, anthracenyl or pyrenyl) and ${ }^{3}$ MLCT excited states was investigated using low temperature $(77 \mathrm{~K})$ 45 measurements on glasses (EtOH: $\left.\mathrm{CHCl}_{3}, 1: 1\right)$ of the corresponding ligands. For example, Figure 6 shows that the vibronically structured triplet emission from the naphthyl moiety $\left({ }^{3} \mathrm{LC}_{\text {nap }}\right)$ for $\mathbf{H L}^{2}$, with an onset $c a .21300 \mathrm{~cm}^{-1}$ lies well above,

Table 3. Electronic spectroscopic data for the complexes.

\begin{tabular}{|c|c|c|c|c|c|c|}
\hline Compound & $\lambda_{\mathrm{abs}}{ }^{a} / \mathrm{nm}$ & $\lambda_{\mathrm{em}}{ }^{a, b} / \mathrm{nm}$ & $\tau^{a, c} / \mathrm{ns}$ & $\tau^{d} / \mu \mathrm{s}$ & $\lambda_{\mathrm{em}}{ }^{e} / \mathrm{nm}$ & $\Phi^{f}$ \\
\hline & & & & $\begin{array}{c}293 \mathrm{~K} \\
\text { (degassed) }\end{array}$ & $77 \mathrm{~K}$ & \\
\hline$\left[\mathrm{Pt}\left(\mathrm{L}^{1}\right)(\mathrm{acac})\right]$ & $300,349,368,417$ & 618 & 380 & 3.4 & - & 0.006 \\
\hline$\left[\mathrm{Pt}\left(\mathrm{L}^{2}\right)(\mathrm{acac})\right]$ & $\begin{array}{l}261,273,284,294 \\
342,359,378,406\end{array}$ & 603 & 543 & 6.6 & $485,520,571$ & 0.021 \\
\hline$\left[\mathrm{Pt}\left(\mathrm{L}^{3}\right)(\mathrm{acac})\right]$ & $\begin{array}{c}257,298,350,362 \\
368,389,413\end{array}$ & 606 & 356 & 2.9 & $453,488,529,578$ & 0.007 \\
\hline$\left[\mathrm{Pt}\left(\mathrm{L}^{4}\right)(\mathrm{acac})\right]$ & $\begin{array}{c}256,266,278,297 \\
314,329,345,361, \\
408\end{array}$ & 603 & 258 & $\begin{array}{c}42.0(95 \%), \\
3.7(5 \%)\end{array}$ & $601,616,652,666$ & 0.005 \\
\hline
\end{tabular}

${ }^{a}$ at $293 \mathrm{~K}$, in aerated chloroform $;{ }^{b}{ }^{3}$ MLCT emission (excited using 350 or $420 \mathrm{~nm}$ ); ${ }^{3}$ MLCT lifetime (excited using 372 or $459 \mathrm{~nm}$ ); ${ }^{d 3} \mathrm{MLCT}$ lifetime in chloroform (excited using $355 \mathrm{~nm}$ ); ${ }^{e}$ in ethanol/chloroform (1:1) glass at $77 \mathrm{~K}$, excited using 350 or $420 \mathrm{~nm} ;{ }^{f}$ quantum yield obtained in aerated chloroform, using $\left[\mathrm{Ru}(\text { bipy })_{3}\right]\left(\mathrm{PF}_{6}\right)_{2}$ in aerated $\mathrm{MeCN}$ as a standard $(\Phi=0.016){ }^{25}$

assigned to naphthyl, anthracenyl or pyrenyl-centred transitions, respectively, all $<400 \mathrm{~nm}$. Room temperature degassed 10 measurements on $\left[\mathrm{Pt}\left(\mathbf{L}^{2-4}\right)(\mathrm{acac})\right]$ showed an increase in the integrated intensity of the ${ }^{3} \mathrm{MLCT}$ emission band, again suggesting a sensitivity to ${ }^{3} \mathrm{O}_{2}$ quenching (Fig. 6).

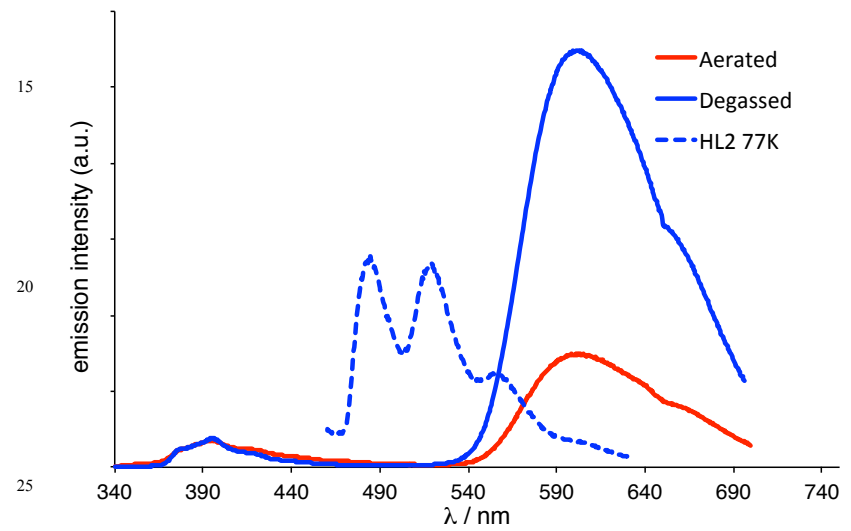

Figure 6. Comparison of the room temperature emission spectra of $\left[\operatorname{Pt}\left(\mathbf{L}^{2}\right)(\mathrm{acac})\right]$ in aerated (red line) and degassed chloroform (blue line). The low temperature emission spectrum of $\mathbf{H L}^{2}$ (blue dashed line) as a 30 glass (EtOH: $\left.\mathrm{CHCl}_{3}, 1: 1\right)$ is shown for comparison.

Lifetime measurements (SI, Fig S7) on $\left[\mathrm{Pt}\left(\mathbf{L}^{2-4}\right)(\mathrm{acac})\right]$ (Table 3) in aerated solvent lie in the range 258-543 ns $\left(c f .\left[\operatorname{Pt}\left(\mathbf{L}^{\mathbf{1}}\right)(\mathrm{acac})\right]\right.$ with $\tau=380 \mathrm{~ns})$ and showed varied sensitivity to solvent degassing. For $\left[\operatorname{Pt}\left(\mathbf{L}^{2}\right)(\mathrm{acac})\right]$ the lifetime of the ${ }^{3} \mathrm{MLCT}$ state in 35 chloroform was $543 \mathrm{~ns}$, which extended to $6.6 \mu \mathrm{s}$ under degassing. Under the same conditions, the properties of the anthracenyl derivative $\left[\operatorname{Pt}\left(\mathbf{L}^{\mathbf{3}}\right)(\right.$ acac $\left.)\right]$ were similar to $\left[\operatorname{Pt}\left(\mathbf{L}^{1}\right)(\mathrm{acac})\right](2.9 \mu \mathrm{s} v s 3.4 \mu \mathrm{s})$. In comparison [ $\left.\mathrm{Pt}\left(\mathbf{L}^{\mathbf{4}}\right)(\mathrm{acac})\right]$, which possessed the shortest aerated ${ }^{3}$ MLCT lifetime of $258 \mathrm{~ns}$,

40 revealed a remarkable extension in this lifetime to $42.0 \mu \mathrm{s}$ when measured under degassed conditions (SI, Fig. S7).

6 | Journal Name, [year], [vol], ๑๑-๑९This journa and with minimal overlap of, the ${ }^{3}$ MLCT state of $\left[\operatorname{Pt}\left(\mathbf{L}^{2}\right)(\right.$ acac $\left.)\right]$, 50 which peaks at $c a .16600 \mathrm{~cm}^{-1}$.

Analogous measurements for $\left[\operatorname{Pt}\left(\mathbf{L}^{4}\right)(\mathrm{acac})\right]$ reveal (Figure 7) typical emission from the triplet state of pyrene $\left({ }^{3} \mathrm{LC}_{\mathrm{pyr}}\right)$ peaking at $c a .16700 \mathrm{~cm}^{-1}$, which is in agreement with previous literature reports. ${ }^{11}$ Figure 7 clearly shows that there is significant spectral 55 overlap of the ${ }^{3} \mathrm{LC}_{\mathrm{pyr}}$ and ${ }^{3} \mathrm{MLCT}$ (peaking at $c a .16600 \mathrm{~cm}^{-1}$ ) bands in $\left[\operatorname{Pt}\left(\mathbf{L}^{4}\right)(\mathrm{acac})\right]$ and suggests that the energy matching of these two states could lie within $<500 \mathrm{~cm}^{-1}$. The dramatic increase in ${ }^{3} \mathrm{MLCT}$ lifetime of $\left[\mathrm{Pt}\left(\mathbf{L}^{4}\right)(\mathrm{acac})\right]$ under degassed conditions suggests that interplay between the two states via 60 through-space energy transfer may result in the thermal equilibration of the ${ }^{3} \mathrm{MLCT}$ and ${ }^{3} \mathrm{LC}_{\mathrm{pyr}}$ states. The good energy matching of the triplet levels of the complex and pyrene chromophore can allow thermal equilibration under degassed solvent conditions, giving rise to the 'energy reservoir' effect ${ }_{65}$ whereby the ${ }^{3} \mathrm{MLCT}$ lifetime is extended by the long-lived ${ }^{3} \mathrm{LC}_{\mathrm{pyr}}$ state (see SI, Scheme S2). ${ }^{11}$ Conversely, under aerated conditions the relatively shortened ${ }^{3} \mathrm{MLCT}$ lifetime of $\left[\mathrm{Pt}\left(\mathbf{L}^{4}\right)(\mathrm{acac})\right]$ versus $\left[\operatorname{Pt}\left(\mathbf{L}^{1}\right)(\mathrm{acac})\right]$ may be due to ${ }^{3} \mathrm{MLCT} \rightarrow{ }^{3} \mathrm{LC}_{\mathrm{pyr}}$ energy transfer that provides a quenching pathway due to efficient deactivation of the ${ }_{70}^{3} \mathrm{LC}_{\text {pyr }}$ by dissolved ${ }^{3} \mathrm{O}_{2}$.

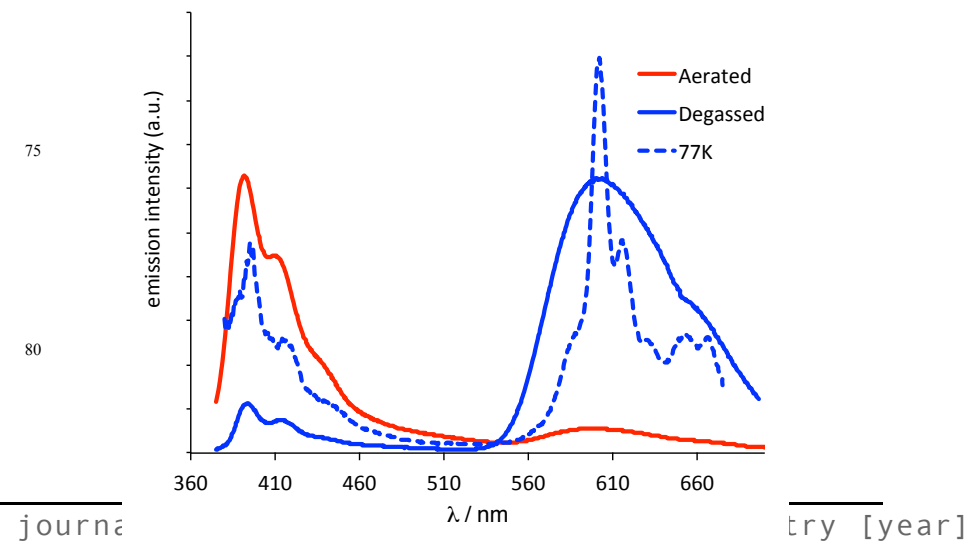


Figure 7. Comparison of the room temperature emission spectra of $\left[\operatorname{Pt}\left(\mathbf{L}^{4}\right)(\right.$ acac $\left.)\right]$ in aerated (red line), degassed chloroform (blue line) with 5 the low temperature (blue dashed line) emission spectrum (EtOH: $\mathrm{CHCl}_{3}$, $1: 1)$.

In contrast to $\left[\operatorname{Pt}\left(\mathbf{L}^{4}\right)(\mathrm{acac})\right]$, the luminescence data for $\left[\operatorname{Pt}\left(\mathbf{L}^{3}\right)(\mathrm{acac})\right]$ suggests that no energy reservoir effect was in operation. In literature reports, the triplet excited state of 10 anthracene $\left({ }^{3} \mathrm{LC}_{\mathrm{anth}}\right)$ has been observed around $14500 \mathrm{~cm}^{-1} \cdot{ }^{26}$ However, in the context of the work herein, luminescence data for 9-(methylaminomethyl)anthracene, as reported by de Melo et $a l .,{ }^{27}$ is much more structurally relevant to the chromophore represented in $\left[\mathrm{Pt}\left(\mathbf{L}^{3}\right)(\mathrm{acac})\right]$. Low temperature measurements on $15\left[\operatorname{Pt}\left(\mathbf{L}^{3}\right)(\right.$ acac $\left.)\right]$ (and $\mathbf{H L}^{3}$ ) suggest that the ${ }^{3} \mathrm{LC}_{\text {anth }}$ state of this anthracenyl chromophore is significantly higher in energy than that known for anthracene, with an onset $c a .22200 \mathrm{~cm}^{-1}$; this is consistent with the previously reported observations for 9(methylaminomethyl)anthracene. ${ }^{36}$ Therefore, for $\left[\operatorname{Pt}\left(\mathbf{L}^{3}\right)(\right.$ acac $\left.)\right]$ it 20 is likely that the ${ }^{3} \mathrm{LC}_{\text {anth }}$ excited state lies well above the ${ }^{3} \mathrm{MLCT}$ state (SI, Scheme S2). This results in poor energy matching of the excited states, yielding ${ }^{3}$ MLCT characteristics which are comparable to the non-chromophoric analogue $\left[\operatorname{Pt}\left(\mathbf{L}^{1}\right)(\right.$ acac $\left.)\right]$.

In summary, this Paper has described the synthetic pathway to 25 lipophilic, chromophore functionalised cyclometalated Pt(II) complexes. These new species have been characterised using a range of spectroscopic and analytical techniques, and two examples have been structurally characterised in the solid state using single crystal X-ray diffraction. Luminescence studies have 30 shown that for the chromophore functionalised complexes dual emission is apparent, with both ligand-based fluorescence and $\mathrm{Pt}(\mathrm{II})$-based ${ }^{3}$ MLCT phosphorescence observed. The intensity of the ${ }^{3}$ MLCT emission was found ot be sensitive to dissolved oxygen. In the case of the pyrene-appended complex ${ }_{35}\left[\operatorname{Pt}\left(\mathbf{L}^{4}\right)(\mathrm{acac})\right]$ degassing led to a dramatic elongation of the ${ }^{3}$ MLCT lifetime, which was attributed to good energetic matching with the pyrene-based triplet state and an energy reservoir effect. For the naphthyl and anthracenyl variants the ligand-based triplet states lie well above the level of the ${ }^{3}$ MLCT ${ }_{40}$ state and therefore do not show the same effect.

\section{Experimental Section}

\section{X-ray crystallography}

Suitable crystals were selected and measured following a standard method ${ }^{28}$ on a Rigaku AFC12 goniometer equipped with 45 an enhanced sensitivity (HG) Saturn 724+ detector mounted at the window of a FR-E+ SuperBright molybdenum rotating anode generator with either VHF Varimax optics (70 $\mu \mathrm{m}$ focus)

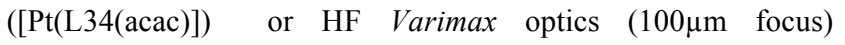
$([\operatorname{Pt}(\mathrm{L} 4)(\mathrm{acac})])$ at $100 \mathrm{~K}$. Cell determination, data collection, ${ }_{50}$ reduction, cell refinement and absorption correction carried out using CrystalClear-SM Expert 3.1b27. ${ }^{29}$

The structures were solved by charge flipping using SUPERFLIP ${ }^{30}$ and were completed by iterative cycles of $\triangle \mathrm{F}$ syntheses and full-matrix least squares refinement. All non- $\mathrm{H}$ 55 atoms were refined anisotropically and difference Fourier syntheses were employed in positioning idealized hydrogen atoms and were allowed to ride on their parent $\mathrm{C}$-atoms. Disordered solvent molecules were modelled using partial occupancy. All refinements were against $\mathrm{F}^{2}$ and used SHELXL602014 . $^{31}$ Figures were created using the ORTEP3 software package. CCDC reference numbers $1443584\left[\mathrm{Pt}\left(\mathrm{L}^{3}\right)(\mathrm{acac})\right]$ and $1443585\left[\mathrm{Pt}\left(\mathrm{L}^{4}\right)(\mathrm{acac})\right]$, contain the supplementary crystallographic data for this paper. These data can be obtained free of charge from the Cambridge Crystallographic Data Centre ${ }_{65}$ via www.ccdc.cam.ac.uk/data request/cif.

\section{DFT Calculations}

All calculations were performed on the Gaussian 09 suite. ${ }^{32}$ Relaxed potential energy scans were calculated by fixing the $\mathrm{O}-$ $\mathrm{C}-\mathrm{N}-\mathrm{C}_{\text {pyrene }}$ dihedral angle, and allowing the structure to 70 optimize at each value of the scanned parameter. The structures corresponding to the minima and maxima of the potential energy surface were thereafter used as a starting geometry for a subsequent transition state calculation. Molecular geometries were optimized without restraints, and were followed by 75 frequency calculations to ascertain the nature of the stationary point (minimum vs. saddle point). Frequency calculations of transition state structures showed only a single imaginary frequency, corresponding to the expected reaction coordinate. Calculations were performed using the restricted B3LYP hybrid 80 functional, ${ }^{33}$ incorporating the D3 version of Grimme's dispersion correction. ${ }^{34}$ The $6-31 \mathrm{G}(\mathrm{d}, \mathrm{p})$ double $\zeta$ basis set was used for all centres. ${ }^{35}$ Coordinates of all optimized structures are provided in the supplementary material.

\section{General}

${ }_{85}^{1} \mathrm{H}$ and ${ }^{13} \mathrm{C}\left\{{ }^{1} \mathrm{H}\right\}$ NMR spectra were run on NMR-FT Bruker 250 or 400 spectrometers, ${ }^{195} \mathrm{Pt}\left\{{ }^{1} \mathrm{H}\right\}$ on NMR-FT 500 spectrometer (all recorded in $\left.\mathrm{CDCl}_{3}\right) .{ }^{1} \mathrm{H}$ and ${ }^{13} \mathrm{C}\left\{{ }^{1} \mathrm{H}\right\}$ NMR chemical shifts $(\delta)$ were determined relative to internal TMS and are given in ppm. Low-resolution mass spectra were obtained by the staff at Cardiff 90 University. High-resolution mass spectra were carried out by at the EPSRC National Mass Spectrometry Service at Swansea University. UV-Vis studies were performed on a Jasco V-570 spectrophotometer as chloroform solutions. Photophysical data were obtained on a JobinYvon-Horiba Fluorolog spectrometer 95 fitted with a JY TBX picosecond photodetection module and a Hamamatsu R5509-73 detector (cooled to $-80^{\circ} \mathrm{C}$ using a C9940 housing). Emission spectra were uncorrected and excitation spectra were instrument corrected. The pulsed sources were either a Nano-LED configured for $372 \mathrm{~nm}$ or $459 \mathrm{~nm}$ output (operating 100 at $500 \mathrm{kHz}$ ) or a Continuum Minilite Nd:YAG laser at $355 \mathrm{~nm}$ (operating at $15 \mathrm{~Hz}$ ). Degassed samples were prepared by a thricely freeze-pump-thaw treatment of solutions using a bespoke cell fitted with a Young's tap and solvent bulb. Luminescence lifetime profiles were obtained using the JobinYvon-Horiba ${ }_{105}$ FluoroHub single photon counting module and the data fits yielded the lifetime values using the provided DAS6 deconvolution software.

\section{Materials}

All reactions were performed with the use of vacuum line and ${ }_{110}$ Schlenk techniques. Reagents were commercial grade and were used without further purification. 2-phenyl-4-quinolinecarboxylic acid and potassium tetrachloroplatinate were used as purchased 
from Alfa Aesar.

\section{General synthesis for $\mathbf{P}^{2-4}$.}

Equimolar aryl aldehyde and 1-octylamine were dissolved in ethanol $(20 \mathrm{~mL})$ and heated at reflux for $16 \mathrm{~h}$ under dinitrogen. 5 The reaction was cooled and $\mathrm{NaBH}_{4}$ (excess) was added in portions. The reaction was stirred for a further $16 \mathrm{~h}$ before dilution with dichloromethane $(20 \mathrm{~mL})$ and then washed with water $(2 \times 20 \mathrm{~mL})$ and brine $(20 \mathrm{~mL})$. The organic phase was dried over $\mathrm{MgSO}_{4}$ before the solvent was removed in vacuo.

Synthesis of $\mathbf{P}^{\mathbf{2}}$ : using 1-naphthaldehyde (0.254 g, $\left.1.628 \mathrm{mmol}\right)$, 1-octylamine $(0.210 \mathrm{~g}, 1.628 \mathrm{mmol})$ and $\mathrm{NaBH}_{4}(0.124 \mathrm{~g}, 3.256$ $\mathrm{mmol})$. The product was obtained as a light yellow oil. Yield = $0.358 \mathrm{~g}(82 \%) .{ }^{1} \mathrm{H}$ NMR $\left(400 \mathrm{MHz}, \mathrm{CDCl}_{3}\right): \delta_{\mathrm{H}} 8.04\left(1 \mathrm{H}, \mathrm{d},{ }^{3} J_{\mathrm{HH}}\right.$ $\left.{ }_{15}=8.0 \mathrm{~Hz}\right), 7.85\left(1 \mathrm{H}, \mathrm{dd}, J_{\mathrm{HH}}=8.0,1.6 \mathrm{~Hz}\right), 7.77\left(1 \mathrm{H}, \mathrm{dd}, J_{\mathrm{HH}}=\right.$ $7.6,1.6 \mathrm{~Hz}), 7.54-7.39(4 \mathrm{H}, \mathrm{m}), 4.21(2 \mathrm{H}, \mathrm{s}), 2.70\left(2 \mathrm{H}, \mathrm{t},{ }^{3} J_{\mathrm{HH}}=\right.$ $7.2 \mathrm{~Hz}), 1.56-1.49(2 \mathrm{H}, \mathrm{m}), 1.33-1.19(10 \mathrm{H}, \mathrm{m}), 0.86(3 \mathrm{H}, \mathrm{t}$, $\left.{ }^{3} J_{\mathrm{HH}}=7.2 \mathrm{~Hz}\right) \mathrm{ppm}$.

${ }_{20}$ Synthesis of $\mathbf{P}^{\mathbf{3}}$ : using 9-anthraldehyde ( $\left.0.163 \mathrm{~g}, 0.789 \mathrm{mmol}\right), 1$ octylamine $(0.102 \mathrm{~g}, 0.789 \mathrm{mmol})$ and $\mathrm{NaBH}_{4}(0.060 \mathrm{~g}, 1.577$ mmol. The product was purified by column chromatography (silica) and was eluted with dichloromethane/methanol (9:1). Yield $=0.242 \mathrm{~g}(96 \%) .{ }^{1} \mathrm{H}$ NMR $\left(400 \mathrm{MHz}, \mathrm{CDCl}_{3}\right): \delta_{\mathrm{H}} 8.41$ ${ }_{25}(1 \mathrm{H}, \mathrm{s}), 8.34\left(2 \mathrm{H}, \mathrm{dd}, J_{\mathrm{HH}}=8.8 \mathrm{~Hz}, 0.8 \mathrm{~Hz}\right), 8.01\left(2 \mathrm{H}, \mathrm{d},{ }^{3} J_{\mathrm{HH}}=\right.$ $8.4 \mathrm{~Hz}), 7.54\left(2 \mathrm{H}, \mathrm{dd}, J_{\mathrm{HH}}=8.8 \mathrm{~Hz}, 6.4,1.2 \mathrm{~Hz}\right), 7.48-7.46(2 \mathrm{H}$, $\mathrm{m}), 4.73(2 \mathrm{H}, \mathrm{s}), 2.87\left(2 \mathrm{H}, \mathrm{t},{ }^{3} J_{\mathrm{HH}}=7.2 \mathrm{~Hz}\right), 1.62-1.55(2 \mathrm{H}, \mathrm{m})$, $1.35-1.23(10 \mathrm{H}, \mathrm{m}), 0.88\left(3 \mathrm{H}, \mathrm{t},{ }^{3} J_{\mathrm{HH}}=1.6 \mathrm{~Hz}\right) \mathrm{ppm}$.

${ }_{30}$ Synthesis of $\mathbf{P}^{\mathbf{4}}$ : using 1-pyrenecarboxaldehyde (0.169 g, 0.733 mmol $)$, 1-octylamine $(0.095 \mathrm{~g}, 0.733 \mathrm{mmol})$ and $\mathrm{NaBH}_{4}(0.056 \mathrm{~g}$, $1.466 \mathrm{mmol})$. The product was purified by column chromatography (silica) and was eluted with dichloromethane/methanol (9:1). Yield $=0.246 \mathrm{~g}(98 \%) .{ }^{1} \mathrm{H}$ ${ }_{35} \mathrm{NMR}\left(400 \mathrm{MHz}, \mathrm{CDCl}_{3}\right): \delta_{\mathrm{H}} 8.35\left(1 \mathrm{H}, \mathrm{d},{ }^{3} J_{\mathrm{HH}}=9.2 \mathrm{~Hz}\right), 8.20-$ $8.16(2 \mathrm{H}, \mathrm{m}), 8.15-8.12(2 \mathrm{H}, \mathrm{m}), 8.04-7.98(4 \mathrm{H}, \mathrm{m}), 4.49(2 \mathrm{H}$, s), $2.79\left(2 \mathrm{H}, \mathrm{t},{ }^{3} J_{\mathrm{HH}}=7.2 \mathrm{~Hz}\right), 1.62-1.54(2 \mathrm{H}, \mathrm{m}), 1.35-1.22$ $(10 \mathrm{H}, \mathrm{m}), 0.88\left(3 \mathrm{H}, \mathrm{t},{ }^{3} J_{\mathrm{HH}}=6.8 \mathrm{~Hz}\right) \mathrm{ppm} .{ }^{13} \mathrm{C}\left\{{ }^{1} \mathrm{H}\right\} \mathrm{NMR}(125.8$ $\left.\mathrm{MHz}, \mathrm{CDCl}_{3}\right): \delta_{\mathrm{C}} 131.3,130.9,130.8,129.2,127.9,127.5,127.4$, $40127.4,127.3,125.9,125.2,125.1,124.7,122.9,50.9,49.3,31.8$, $29.4,29.3,29.2,27.3,22.6,14.1 \mathrm{ppm}$. MS(ES) found $m / z=344.2$ $[\mathrm{M}+\mathrm{H}]^{+} . \mathrm{UV}$-vis $\left(\mathrm{CHCl}_{3}\right): \lambda_{\max }\left(\varepsilon / \mathrm{dm}^{3} \mathrm{~mol}^{-1} \mathrm{~cm}^{-1}\right) 266$ (23400), 277 (39600), 300 (4720), 314 (11400), 327 (26700), 344 (39000) $\mathrm{nm}$. IR (thin film): $v_{\max } 3040,2953,2928,2855,2816,1603$, ${ }_{45} 1587,1458,1443,1184,1096,841,802,710 \mathrm{~cm}^{-1}$.

\section{General method for the synthesis of the ligands ${ }^{36}$}

Thionyl chloride (excess) was added, dropwise, to a stirring suspension of 2-phenyl-4-quinolinecarboxylic acid (1.1 eq.) in chloroform $(10 \mathrm{~mL})$. The reaction was heated at reflux for $16 \mathrm{~h}$ so under dinitrogen. The solvent was removed in vacuo and the yellow solid, 2-phenyl-4-quinolinecarbonyl chloride, redissolved in chloroform $(10 \mathrm{~mL})$ before the amine (1 eq.) was added slowly to the stirring solution. $\mathrm{EtN}^{i} \mathrm{Pr}_{2}$ (excess) was added dropwise and the mixture was stirred for $16 \mathrm{~h}$ at room temperature under ${ }_{55}$ dinitrogen. The solvent was removed in vacuo before being redissolved in dichloromethane $(20 \mathrm{~mL})$. The crude mixture was washed with $\mathrm{NaHCO}_{3}$ (sat. sol., $2 \times 20 \mathrm{~mL}$ ), water $(1 \times 20 \mathrm{~mL}$ ) and brine $(1 \times 20 \mathrm{~mL})$. The organic phase was dried over $\mathrm{MgSO}_{4}$ and filtered before the solvent was removed in vacuo.

60

Synthesis of HL $^{\mathbf{1}}$ : using 2-phenyl-4-quinolinecarboxylic acid $(0.465 \mathrm{~g}, 1.869 \mathrm{mmol})$ and 1-octylamine $(0.219 \mathrm{~g}, 1.699 \mathrm{mmol})$. Yield $=0.434 \mathrm{~g}(71 \%) .{ }^{1} \mathrm{H}$ NMR $\left(400 \mathrm{MHz}, \mathrm{CDCl}_{3}\right): \delta_{\mathrm{H}} 7.98$ $\left(1 \mathrm{H}, \mathrm{d},{ }^{3} J_{\mathrm{HH}}=8.4 \mathrm{~Hz}\right), 7.94-7.91(2 \mathrm{H}, \mathrm{m}), 7.84\left(1 \mathrm{H}, \mathrm{d},{ }^{3} J_{\mathrm{HH}}=\right.$ $\left.{ }_{65} 8.0 \mathrm{~Hz}\right), 7.60-7.56(1 \mathrm{H}, \mathrm{m}), 7.51(1 \mathrm{H}, \mathrm{s}), 7.42-7.40(3 \mathrm{H}, \mathrm{m})$, $7.33-7.29(1 \mathrm{H}, \mathrm{m}), 6.93\left(1 \mathrm{H}\right.$, br. t, $\left.{ }^{3} J_{\mathrm{HH}}=4.4 \mathrm{~Hz}\right), 3.35-3.30$ $(2 \mathrm{H}, \mathrm{m}), 1.59-1.52(2 \mathrm{H}, \mathrm{m}), 1.34-1.19(10 \mathrm{H}, \mathrm{m}), 0.90(3 \mathrm{H}, \mathrm{t}$, $\left.{ }^{3} J_{\mathrm{HH}}=6.4 \mathrm{~Hz}\right) \mathrm{ppm} .{ }^{13} \mathrm{C}\left\{{ }^{1} \mathrm{H}\right\} \mathrm{NMR}\left(75.6 \mathrm{MHz}, \mathrm{CDCl}_{3}\right): \delta_{\mathrm{C}} 167.6$, $156.7,148.5,143.4,138.7,130.3,129.9,129.0,127.5,127.3$, $70125.1,123.4,116.4,40.3,31.9,29.7,29.4,27.1,22.8,14.2 \mathrm{ppm}$. MS (ES) found $m / z=361.22[\mathrm{M}+\mathrm{H}]^{+}$. UV-vis $\left(\varepsilon / \mathrm{M}^{-1} \mathrm{~cm}^{-1}\right)$ $\left(\mathrm{CHCl}_{3}\right) \lambda_{\max }: 263$ (29100), 327 (6610) nm. IR $v_{\max }$ (thin film): $3306(\mathrm{~N}-\mathrm{H}), 1636(\mathrm{C}=\mathrm{O}) \mathrm{cm}^{-1}$.

${ }_{75}$ Synthesis of $\mathbf{H L}^{2}$ : using 2-phenyl-4-quinolinecarboxylic acid $(0.235 \mathrm{~g}, 0.941 \mathrm{mmol})$ and $\mathrm{P}^{2}(0.231 \mathrm{~g}, 0.855 \mathrm{mmol}$. Yield $=$ $0.268 \mathrm{~g}(89 \%) .{ }^{1} \mathrm{H}$ NMR $\left(400 \mathrm{MHz}, \mathrm{CDCl}_{3}\right)$ : major isomer $\delta_{\mathrm{H}}$ $8.42\left(1 \mathrm{H}, \mathrm{d},{ }^{3} J_{\mathrm{HH}}=8.4 \mathrm{~Hz}\right), 8.19-7.32(16 \mathrm{H}, \mathrm{m}), 5.72(1 \mathrm{H}, \mathrm{d}$, $\left.{ }^{2} J_{\mathrm{HH}}=14.4 \mathrm{~Hz}, \mathrm{CHH}\right), 5.18\left(1 \mathrm{H}, \mathrm{d},{ }^{2} J_{\mathrm{HH}}=14.4 \mathrm{~Hz}, \mathrm{CH} H\right), 2.94-$ $802.80(2 \mathrm{H}, \mathrm{m}), 1.47-0.86(12 \mathrm{H}, \mathrm{m}), 0.79\left(3 \mathrm{H}, \mathrm{t},{ }^{3} J_{\mathrm{HH}}=6.8 \mathrm{~Hz}\right)$ ppm; minor isomer $\delta_{\mathrm{H}} 8.19-7.32(17 \mathrm{H}, \mathrm{m}), 4.92-4.72(2 \mathrm{H}$, br. $\mathrm{m}), 2.94-2.80(2 \mathrm{H}, \mathrm{m}), 1.92-1.79(2 \mathrm{H}$, br. m) $1.47-0.86$ (13H, m) ppm. ${ }^{13} \mathrm{C}\left\{{ }^{1} \mathrm{H}\right\}$ NMR (125.8 MHz, $\left.\mathrm{CDCl}_{3}\right)$ : Both isomers $\delta_{\mathrm{C}} 167.7,155.8,147.4,142.7,138.1,130.5,130.4,129.2$, ${ }_{85} 129.1,128.6,128.5,127.9,127.7,126.4,126.4,126.1,125.8$, $124.3,123.7,123.1,122.2,114.9,45.7,38.0,30.4,28.1,27.6$, 27.4, 25.2, 21.4, 13.0 ppm. HR-MS: calcd. 501.2900 for $\left[\mathrm{C}_{35} \mathrm{H}_{37} \mathrm{~N}_{2} \mathrm{O}\right]^{+}$, found $m / z=501.2889$. UV-vis $\left(\mathrm{CHCl}_{3}\right): \lambda_{\max }(\varepsilon /$ $\left.\mathrm{dm}^{3} \mathrm{~mol}^{-1} \mathrm{~cm}^{-1}\right) 263$ (46500), 282 (19400), 293 (15600), 312 90 (8980), 325 (8880), $336(7570) \mathrm{nm}$. IR (thin film): $v_{\max } 3059$, 2926, 2853, 1638, 1597, 1549, 1510, 1466, 1460, 1406, 1377, $1348,1248,1028,793,772,760,741,694,665 \mathrm{~cm}^{-1}$.

Synthesis of $\mathbf{H L}^{3}$ : using 2-phenyl-4-quinolinecarboxylic acid ${ }_{95}(0.163 \mathrm{~g}, 0.656 \mathrm{mmol})$ and $\mathrm{P}^{3}(0.190 \mathrm{~g}, 0.596 \mathrm{mmol})$. Yield $=$ $0.282 \mathrm{~g}(86 \%) .{ }^{1} \mathrm{H}$ NMR $\left(400 \mathrm{MHz}, \mathrm{CDCl}_{3}\right): \delta_{\mathrm{H}} 8.58-8.54(3 \mathrm{H}$, m), $8.17-8.08(5 \mathrm{H}, \mathrm{m}), 7.84(1 \mathrm{H}, \mathrm{s}), 7.80\left(1 \mathrm{H}, \mathrm{d},{ }^{3} J_{\mathrm{HH}}=7.2 \mathrm{~Hz}\right)$, $7.71-7.65(3 \mathrm{H}, \mathrm{m}), 7.58-7.46(5 \mathrm{H}, \mathrm{m}), 7.39(1 \mathrm{H}, \mathrm{m}), 6.28(1 \mathrm{H}$, $\left.\mathrm{d},{ }^{2} J_{\mathrm{HH}}=15.2 \mathrm{~Hz}, \mathrm{CHH}\right), 5.82\left(1 \mathrm{H}, \mathrm{d},{ }^{2} J_{\mathrm{HH}}=15.2 \mathrm{~Hz}, \mathrm{CH} H\right)$, $1002.51(2 \mathrm{H}$, app. t), $1.39-1.25(2 \mathrm{H}$, br m), $1.08-0.53(13 \mathrm{H}$, overlapping m) ppm. ${ }^{13} \mathrm{C}\left\{{ }^{1} \mathrm{H}\right\}$ NMR $\left(125.8 \mathrm{MHz}, \mathrm{d}_{6}\right.$-DMSO): $\delta_{\mathrm{C}}$ $167.7,155.8,147.4,142.7,138.1,130.5,130.4,130.2,129.2$, $129.1,128.6,128.5,128.0,127.9,127.7,126.6,126.4,126.4$, $126.2,126.1,125.8,125.6,124.3,124.0,123.7,123.1,122.2$, $105114.9,45.7,38.0,30.6,30.4,28.1,27.9,27.8,27.6,27.4,26.9$, 25.8, 25.2, 21.5, 21.4, 13.1, 12.9 ppm. HR-MS: calcd. 551.3057 for $\left[\mathrm{C}_{39} \mathrm{H}_{39} \mathrm{~N}_{2} \mathrm{O}\right]^{+}$, found $m / z=551.3051$. UV-vis $\left(\mathrm{CHCl}_{3}\right): \lambda_{\max }(\varepsilon$ $\left./ \mathrm{dm}^{3} \mathrm{~mol}^{-1} \mathrm{~cm}^{-1}\right) 258$ (55700), 333 (7980), 350 (5680), 368 (6960), 389 (6320) nm. IR (thin film): $v_{\max } 3057,2955,2924$, ${ }_{110} 2855,1628,1593,1549,1495,1462,1447,1431,1406,1373$, $1343,1263,1240,1180,1159,1123,1028,889,767,759 \mathrm{~cm}^{-1}$.

Synthesis of $\mathbf{H L}^{4}$ : using 2-phenyl-4-quinolinecarboxylic acid $(0.235 \mathrm{~g}, 0.941 \mathrm{mmol})$ and $\mathrm{P}^{4}(0.231 \mathrm{~g}, 0.855 \mathrm{mmol})$. Yield $=$ $1150.268 \mathrm{~g},(89 \%) .{ }^{1} \mathrm{H} \mathrm{NMR}\left(400 \mathrm{MHz}, \mathrm{CDCl}_{3}\right)$ : major isomer $\delta_{\mathrm{H}}$

8 I Journal Name, [year], [vol], O๑-@๑This journal is @ The Royal Society of Chemistry [year] 
$8.55\left(1 \mathrm{H}, \mathrm{d},{ }^{3} J_{\mathrm{HH}}=8.0 \mathrm{~Hz}\right), 8.22-7.05(18 \mathrm{H}, \mathrm{m}), 5.92(1 \mathrm{H}, \mathrm{d}$, $\left.{ }^{2} J_{\mathrm{HH}}=14.5 \mathrm{~Hz}, \mathrm{CHH}\right), 5.18\left(1 \mathrm{H}, \mathrm{d},{ }^{2} J_{\mathrm{HH}}=14.4 \mathrm{~Hz}, \mathrm{CH} H\right), 2.76$ $\left(2 \mathrm{H}\right.$, app. q), $1.92-0.86(12 \mathrm{H}, \mathrm{m}), 0.66\left(3 \mathrm{H}, \mathrm{t},{ }^{3} J_{\mathrm{HH}}=6.8 \mathrm{~Hz}\right)$ ppm; minor isomer $\delta_{\mathrm{H}} 8.22-7.05(19 \mathrm{H}, \mathrm{m}), 4.92-4.72(2 \mathrm{H}$, br. 5 app. q), $4.31-4.11(1 \mathrm{H}$, br. s), $3.38-3.16(1 \mathrm{H}$, br. s), $1.92-$ $0.72(15 \mathrm{H}$, overlapping m) ppm. HR-MS: calcd. 575.3057 for $\left[\mathrm{C}_{41} \mathrm{H}_{39} \mathrm{~N}_{2} \mathrm{O}\right]^{+}$, found $m / z=575.3046$. UV-vis $\left(\mathrm{CHCl}_{3}\right): \lambda_{\max }(\varepsilon /$ $\left.\mathrm{dm}^{3} \mathrm{~mol}^{-1} \mathrm{~cm}^{-1}\right) 259$ (46000), 264 (49000), 277 (47800), 302 (12200), 314 (18600), 328 (32800), 345 (38100) nm. IR (thin 10 film): $v_{\max } 3045,2926,2855,1634,1628,1593,1549,1435$, 1406, 1373, 1344, 1296, 1263, 1238, 1198, 1184, 1155, 1123, $1028,889,847,768,733,694 \mathrm{~cm}^{-1}$.

\section{Synthesis of platinum (II) complexes}

General method for the complexes ${ }^{17}$

15 A solution of potassium tetrachloroplatinate (II) (1 eq.) in water $(2 \mathrm{~mL})$ was added to a stirring solution of $\mathrm{HL}^{\mathrm{n}}$ (1 eq.) in 2ethoxyethanol $(6 \mathrm{~mL})$ under dinitrogen and heated to $80^{\circ} \mathrm{C}$ for 16 $\mathrm{h}$ in a foil-wrapped flask. Brine $(10 \mathrm{~mL})$ was added to the cooled solution and the resultant precipitate was collected on a sinter and 20 washed with water $(2 \times 10 \mathrm{~mL})$ and dried. The solid was used without purification. Crude $\left[\mathrm{Pt}(\mathrm{L})-\mu-\mathrm{Cl}_{2} \mathrm{Pt}(\mathrm{L})\right]$ was then dissolved in a minimum volume of DMSO before being precipitated with brine $(10 \mathrm{~mL})$, filtered on a sinter and washed with water $(2 \times 20$ $\mathrm{mL})$. [Pt(L)(DMSO)Cl] (1 eq) was dissolved in 3-pentanone (5 $25 \mathrm{~mL})$, to which sodium acetylacetonate $(1-10 \mathrm{eq})$ was added. The reaction was stirred at room temperature for $16 \mathrm{~h}$ under dinitrogen. The solvent was removed in vacuo and the crude product dissolved in dichloromethane $(10 \mathrm{~mL})$ and filtered to remove any insoluble salts. The yellow solution was dried in 30 vacuo. The crude products were purified by column chromatography (silica) and were eluted as the first yellow band with dichloromethane and dried in vacuo.

Synthesis of $\left[\mathbf{P t}\left(\mathbf{L}^{\mathbf{1}}\right)(\mathbf{a c a c})\right]:{ }^{17 \mathrm{~b}}$ using $\left[\mathrm{Pt}\left(\mathrm{L}^{1}\right)(\mathrm{DMSO}) \mathrm{Cl}\right](0.044$ $\left.{ }_{35} \mathrm{~g}, 0.066 \mathrm{mmol}\right)$ and sodium acetylacetonate monohydrate $(0.080$ $\mathrm{g}, 0.660 \mathrm{mmol})$. Obtained as a dark yellow solid. Yield $=0.038 \mathrm{~g}$, $(89 \%) .{ }^{1} \mathrm{H}$ NMR $\left(400 \mathrm{MHz}, \mathrm{CDCl}_{3}\right): \delta_{\mathrm{H}} 9.43\left(1 \mathrm{H}, \mathrm{d},{ }^{3} J_{\mathrm{HH}}=8.8\right.$ $\mathrm{Hz}), 8.00\left(1 \mathrm{H}, \mathrm{dd}, J_{\mathrm{HH}}=8.4,1.2 \mathrm{~Hz}\right), 7.70-7.64(2 \mathrm{H}, \mathrm{m}), 7.57$ $(1 \mathrm{H}, \mathrm{s}), 7.51-7.47(1 \mathrm{H}, \mathrm{m}), 7.33\left(1 \mathrm{H}, \mathrm{dd}, J_{\mathrm{HH}}=8.0,1.2 \mathrm{~Hz}\right)$, ${ }_{40} 7.17-7.13(1 \mathrm{H}, \mathrm{m}), 7.02-6.98(1 \mathrm{H}, \mathrm{m}), 6.66\left(1 \mathrm{H}\right.$, br. t, ${ }^{3} J_{\mathrm{HH}}=$ $6.0 \mathrm{~Hz}, \mathrm{NH}), 5.57(1 \mathrm{H}, \mathrm{s}, \mathrm{acac}), 3.55-3.50(2 \mathrm{H}, \mathrm{m}), 2.04(3 \mathrm{H}, \mathrm{s}$, acac), $2.03(3 \mathrm{H}, \mathrm{s}, \mathrm{acac}), 1.75-1.67(2 \mathrm{H}, \mathrm{m}), 1.45-1.28(10 \mathrm{H}$, $\mathrm{m}), 0.91\left(3 \mathrm{H}, \mathrm{t},{ }^{3} \mathrm{~J}_{\mathrm{HH}}=6.8 \mathrm{~Hz}\right) \mathrm{ppm} .{ }^{13} \mathrm{C}\left\{{ }^{1} \mathrm{H}\right\} \mathrm{NMR}(75.6 \mathrm{MHz}$, $\left.\mathrm{CDCl}_{3}\right): \delta_{\mathrm{C}} 185.7,184.0,169.3,166.8,149.4,145.7,144.7,139.8$, ${ }_{45} 131.0,129.7,129.6,127.1,126.5,125.2,125.1,124.5,124.0$, $114.2,101.9,40.3,31.9,29.8,29.4,28.5,27.3,27.2,22.8,14.2$ ppm. ${ }^{195} \mathrm{Pt}\left\{{ }^{1} \mathrm{H}\right\}$ NMR (107.51 MHz, $\left.\mathrm{CDCl}_{3}\right): \delta_{\mathrm{Pt}}-2776 \mathrm{ppm}$. MS(ES) found $m / z=652.2[\mathrm{M}-\mathrm{H}]^{-}$. UV-vis $\left(\mathrm{CHCl}_{3}\right): \lambda_{\max }(\varepsilon /$ $\left.\mathrm{dm}^{3} \mathrm{~mol}^{-1} \mathrm{~cm}^{-1}\right) 300$ (9920), 349 (2810), 368 (3130), 423 (2420) ${ }_{50} \mathrm{~nm}$. IR (thin film): $v_{\max } 3268(\mathrm{NH}), 1643(\mathrm{C}=\mathrm{O}), 1582(\mathrm{C}=\mathrm{O}) \mathrm{cm}^{-}$ 1 .

Synthesis of $\left[\mathbf{P t}\left(\mathbf{L}^{2}\right)(\mathbf{a c a c})\right]$ : using $\left[\mathrm{Pt}\left(\mathrm{L}^{2}\right)(\mathrm{DMSO}) \mathrm{Cl}\right](0.041 \mathrm{~g}$, $0.051 \mathrm{mmol})$ and sodium acetylacetonate monohydrate $(0.062 \mathrm{~g}$, $\left.{ }_{55} 0.508 \mathrm{mmol}\right)$. The product was purified by column chromatography (silica) and was eluted as the first yellow band with dichloromethane and dried to yield a dark yellow solid. Yield $=0.034 \mathrm{~g},(85 \%) .{ }^{1} \mathrm{H}$ NMR $\left(400 \mathrm{MHz}, \mathrm{CDCl}_{3}\right)$ : major isomer $\delta_{\mathrm{H}} 9.59\left(1 \mathrm{H}, \mathrm{d},{ }^{3} J_{\mathrm{HH}}=8.4 \mathrm{~Hz}\right), 8.39\left(1 \mathrm{H}, \mathrm{d},{ }^{3} J_{\mathrm{HH}}=8.0\right.$ $\left.{ }_{60} \mathrm{~Hz}\right), 7.91\left(1 \mathrm{H}, \mathrm{d},{ }^{3} J_{\mathrm{HH}}=8.0 \mathrm{~Hz}\right), 7.90\left(1 \mathrm{H}, \mathrm{d},{ }^{3} J_{\mathrm{HH}}=8.4 \mathrm{~Hz}\right)$, $7.90-7.23(9 \mathrm{H}, \mathrm{m}), 7.17-7.11(3 \mathrm{H}, \mathrm{m}), 5.71\left(1 \mathrm{H}, \mathrm{d},{ }^{2} J_{\mathrm{HH}}=14.8\right.$ $\mathrm{Hz}, \mathrm{CHH}), 5.57(1 \mathrm{H}, \mathrm{s}, \mathrm{acac}), 5.15\left(1 \mathrm{H}, \mathrm{d},{ }^{2} J_{\mathrm{HH}}=14.8 \mathrm{~Hz}, \mathrm{CH} H\right)$, $2.80(2 \mathrm{H}$, app. q), 2.05 (3H, s, acac), $2.03(3 \mathrm{H}, \mathrm{s}, \mathrm{acac}), 1.91-$ $0.89(12 \mathrm{H}, \mathrm{m}), 0.71\left(3 \mathrm{H}, \mathrm{t},{ }^{3} J_{\mathrm{HH}}=7.2 \mathrm{~Hz}\right) \mathrm{ppm}$; minor isomer $\delta_{\mathrm{H}}$ ${ }_{65} 9.56\left(1 \mathrm{H}, \mathrm{d},{ }^{3} J_{\mathrm{HH}}=8.8 \mathrm{~Hz}\right), 7.97\left(1 \mathrm{H}, \mathrm{d},{ }^{3} J_{\mathrm{HH}}=7.6 \mathrm{~Hz}\right), 7.82-$ $7.05(13 \mathrm{H}, \mathrm{m}), 6.95$ (1H, app. t), $5.45(1 \mathrm{H}, \mathrm{s}$, acac), $4.89-4.78$ $\left(2 \mathrm{H}\right.$, br. m, $\left.\mathrm{CH}_{2}\right), 4.22-4.05(1 \mathrm{H}$, br. m), $3.35-3.20(1 \mathrm{H}$, br. m), $2.92-2.80(2 \mathrm{H}, \mathrm{m}), 2.01(3 \mathrm{H}, \mathrm{s}, \mathrm{acac}), 2.00(3 \mathrm{H}, \mathrm{s}, \mathrm{acac})$, $1.91-0.89\left(13 \mathrm{H}, \mathrm{t},{ }^{3} J_{\mathrm{HH}}=6.8 \mathrm{~Hz}\right) \mathrm{ppm} .{ }^{13} \mathrm{C}\left\{{ }^{1} \mathrm{H}\right\}$ NMR $(151.2$ 70 $\left.\mathrm{MHz}, \mathrm{CDCl}_{3}\right)$ : both isomers $\delta_{\mathrm{C}} 184.5,184.4,183.2,183.1,168.8$, $168.6,167.3,166.7,148.5,148.5,144.8,144.7,144.6,143.8$, $139.1,133.1,132.8,130.9,130.8,130.3,130.2,130.2,129.7$, $129.0,128.9,128.6,128.5,128.2,128.0,128.0,127.9,127.9$, $127.7,127.2,126.5,126.2,126.1,126.0,125.9,125.6,125.4$, $75123.9,123.8,123.7,123.3,123.1,123.0,123.0,122.8,121.0$, $114.8,112.6,112.1,100.8,100.7,49.1,46.1,44.8,43.9,34.4$, $30.8,30.6,28.3,28.2,27.9,27.9,27.3,27.3,27.0,26.6,26.2$, 26.1, 25.4, 21.6, 21.5, 13.1, 13.0 ppm. ${ }^{195} \mathrm{Pt}\left\{{ }^{1} \mathrm{H}\right\}(107.51 \mathrm{MHz}$, $\left.\mathrm{CDCl}_{3}\right): \delta_{\mathrm{Pt}}-2784 \mathrm{ppm}$. UV-vis $\left(\mathrm{CHCl}_{3}\right): \lambda_{\max }\left(\varepsilon / \mathrm{dm}^{3} \mathrm{~mol}^{-1} \mathrm{~cm}^{-1}\right)$ 80261 (12500), 273 (12500), 284 (13600), 294 (12700), 342 (4140), 359 (4370), 378 (3070), 406 (2450) nm. IR (thin film): $v_{\max }$ $(\mathrm{C}=\mathrm{O}), 1580(\mathrm{C}=\mathrm{O}) \mathrm{cm}^{-1}$.

Synthesis of $\left[\operatorname{Pt}\left(\mathbf{L}^{3}\right)(\mathbf{a c a c})\right]$ : using $\left[\mathrm{Pt}\left(\mathrm{L}^{3}\right)(\mathrm{DMSO}) \mathrm{Cl}\right](0.095 \mathrm{~g}$, $\left.{ }_{85} 0.111 \mathrm{mmol}\right)$ and sodium acetylacetonate monohydrate $(0.135 \mathrm{~g}$, $1.109 \mathrm{mmol})$. The product was purified by column chromatography (silica). The product was eluted as the first yellow band with dichloromethane and dried to yield a dark yellow solid. Yield $=0.068 \mathrm{~g},(73 \%) .{ }^{1} \mathrm{H}$ NMR $(400 \mathrm{MHz}$, $\left.{ }_{90} \mathrm{CDCl}_{3}\right): \delta_{\mathrm{H}} 9.58\left(1 \mathrm{H}, \mathrm{d},{ }^{3} J_{\mathrm{HH}}=8.8 \mathrm{~Hz}\right), 8.56-8.54(3 \mathrm{H}, \mathrm{m}), 8.11$ $\left(2 \mathrm{H}, \mathrm{dd},{ }^{3} J_{\mathrm{HH}}=8.4 \mathrm{~Hz}, 0.8 \mathrm{~Hz}\right), 7.74-7.65(6 \mathrm{H}, \mathrm{m}), 7.59-7.55$ $(2 \mathrm{H}, \mathrm{m}), 7.49\left(1 \mathrm{H}, \mathrm{dd}, J_{\mathrm{HH}}=7.6 \mathrm{~Hz}, 0.8 \mathrm{~Hz}\right), 7.38-7.34(1 \mathrm{H}$, m), $7.26-7.23(1 \mathrm{H}, \mathrm{m}), 7.17-7.14(1 \mathrm{H}, \mathrm{m}), 6.27\left(1 \mathrm{H}, \mathrm{d},{ }^{2} J_{\mathrm{HH}}=\right.$ $15.2 \mathrm{~Hz}, \mathrm{CHH}), 5.81\left(1 \mathrm{H}, \mathrm{d},{ }^{2} J_{\mathrm{HH}}=15.2 \mathrm{~Hz}, \mathrm{CH} H\right), 5.56(1 \mathrm{H}, \mathrm{s}$, $\left.{ }_{95} \mathrm{acac}\right), 2.56\left(2 \mathrm{H}, \mathrm{t},{ }^{3} \mathrm{~J}_{\mathrm{HH}}=8.0 \mathrm{~Hz}\right), 2.04(3 \mathrm{H}, \mathrm{s}, \mathrm{acac}), 2.02(3 \mathrm{H}, \mathrm{s}$, acac), $1.42-1.22(2 \mathrm{H}, \mathrm{m}), 1.13-1.04(2 \mathrm{H}, \mathrm{m}), 0.99-0.82(6 \mathrm{H}$, $\mathrm{m}), 0.77\left(3 \mathrm{H}, \mathrm{t},{ }^{3} J_{\mathrm{HH}}=7.2 \mathrm{~Hz}\right), 0.75-0.68(2 \mathrm{H}, \mathrm{m}) \mathrm{ppm}$. ${ }^{13} \mathrm{C}\left\{{ }^{1} \mathrm{H}\right\}$ NMR $\left(125.8 \mathrm{MHz}, \mathrm{CDCl}_{3}\right): \delta_{\mathrm{C}} 185.5,184.2,169.8$, $167.9,149.5,145.8,145.5,140.0,134.1,133.6,131.5,131.4$, $100131.2,131.1,130.9,130.0,129.6,129.5,129.3,128.8,127.2$, $127.1,126.9,126.8,126.7,125.3,125.0,124.9,124.8,124.2$, $124.0,123.9,123.0,113.8,101.7,53.4,46.7,46.0,45.4,39.1$, $35.4,31.4,30.9,29.2,29.0,28.9,28.7,28.6,28.3,27.9,27.2$, 26.9, 26.3, 22.6, 22.4, 14.1, 14.0 ppm. ${ }^{195} \mathrm{Pt}\left\{{ }^{1} \mathrm{H}\right\}(107.51 \mathrm{MHz}$, $\left.{ }_{105} \mathrm{CDCl}_{3}\right): \quad \delta_{\mathrm{Pt}}-2786$ ppm. HR-MS: calcd. for 859.3001 $\left[\mathrm{C}_{44} \mathrm{H}_{44} \mathrm{~N}_{2} \mathrm{O}_{4}{ }^{194} \mathrm{Pt}\right]^{+}$, found $\mathrm{m} / z=859.3009$. UV-vis $\left(\mathrm{CHCl}_{3}\right): \lambda_{\max }$ $\left(\varepsilon / \mathrm{dm}^{3} \mathrm{~mol}^{-1} \mathrm{~cm}^{-1}\right) 257$ (44000), 298 (14800), 350 (6870), 362 (6930), 368 (7440), 389 (6850), 413 (3860) nm. IR (thin film): $v_{\max } 1674(\mathrm{C}=\mathrm{O}), 1582(\mathrm{C}=\mathrm{O}) \mathrm{cm}^{-1}$.

110

Synthesis of $\left[\mathbf{P t}\left(\mathbf{L}^{4}\right)\right.$ (acac) $]$ : using $\left[\mathrm{Pt}\left(\mathrm{L}^{4}\right)(\mathrm{DMSO}) \mathrm{Cl}\right](0.050 \mathrm{~g}$, $0.057 \mathrm{mmol})$ and sodium acetylacetonate monohydrate $(0.069 \mathrm{~g}$, $0.568 \mathrm{mmol})$. The product was purified by column chromatography (silica) and was eluted as the first yellow band 15 with dichloromethane and dried to yield a dark yellow solid. Yield $=0.068 \mathrm{~g},(73 \%) .{ }^{1} \mathrm{H}$ NMR $\left(400 \mathrm{MHz}, \mathrm{CDCl}_{3}\right)$ : major 
isomer $\delta_{\mathrm{H}} 9.59\left(1 \mathrm{H}, \mathrm{d},{ }^{3} J_{\mathrm{HH}}=8.4 \mathrm{~Hz}\right), 8.63\left(1 \mathrm{H}, \mathrm{d},{ }^{3} J_{\mathrm{HH}}=9.2\right.$ $\mathrm{Hz}), 8.32-7.50(11 \mathrm{H}, \mathrm{m}), 7.41(1 \mathrm{H}, \mathrm{d}), 7.31(1 \mathrm{H}$, app. t), $7.16-$ $7.08(3 \mathrm{H}, \mathrm{m}), 6.01\left(1 \mathrm{H}, \mathrm{d},{ }^{2} J_{\mathrm{HH}}=14.4 \mathrm{~Hz}, \mathrm{CHH}\right), 5.56(1 \mathrm{H}, \mathrm{s}$, acac), $5.40\left(1 \mathrm{H}, \mathrm{d},{ }^{2} J_{\mathrm{HH}}=14.8 \mathrm{~Hz}, \mathrm{CH} H\right), 2.86(2 \mathrm{H}$, app. q), 2.04 5 $(3 \mathrm{H}, \mathrm{s}), 2.02(3 \mathrm{H}, \mathrm{s}), 1.56-1.46(2 \mathrm{H}, \mathrm{m}), 1.41-0.90(10 \mathrm{H}, \mathrm{m})$, $0.78\left(3 \mathrm{H}, \mathrm{t},{ }^{3} J_{\mathrm{HH}}=7.2 \mathrm{~Hz}\right) \mathrm{ppm}$; minor isomer $\delta_{\mathrm{H}} 9.55(1 \mathrm{H}, \mathrm{d}$, $\left.{ }^{3} J_{\mathrm{HH}}=8.8 \mathrm{~Hz}\right), 8.32-7.50(13 \mathrm{H}, \mathrm{m}), 7.47(1 \mathrm{H}$, app. t), $7.16-$ $7.08(2 \mathrm{H}, \mathrm{m}), 6.89(1 \mathrm{H}$, app. t), $5.53(1 \mathrm{H}, \mathrm{s}, \mathrm{acac}), 5.16-5.05$ $\left(2 \mathrm{H}\right.$, br. $\left.\mathrm{m}, \mathrm{CH}_{2}\right), 4.13-4.02(1 \mathrm{H}$, br. $\mathrm{m}), 3.44-3.33(1 \mathrm{H}$, br. $10 \mathrm{~m}), 2.01$ (3H, s, acac), $2.00(3 \mathrm{H}, \mathrm{s}, \mathrm{acac}), 1.90-1.80(2 \mathrm{H}$, br. m), $1.41-0.90(10 \mathrm{H}, \mathrm{m}), 0.87\left(3 \mathrm{H}, \mathrm{t},{ }^{3} J_{\mathrm{HH}}=7.2 \mathrm{~Hz}\right) \mathrm{ppm} .{ }^{13} \mathrm{C}\left\{{ }^{1} \mathrm{H}\right\}$ NMR $\left(125.8 \mathrm{MHz}, \mathrm{CDCl}_{3}\right)$ : both isomers $\delta_{\mathrm{C}} 184.5,184.4,183.2$, $183.1,168.8,168.7,167.2,166.7,148.5,144.8,144.6,144.5$, $144.0,139.1,138.9,130.6,130.3,130.2,130.1,129.9,129.5$, $15129.0,128.8,128.7,128.6,128.5,128.4,127.5,127.4,127.3$, $126.9,126.8,126.3,126.2,126.0,125.8,125.3,125.1,124.6$, $124.5,124.3,123.9,123.8,123.7,123.6,123.5,123.4,123.2$, $122.9,122.7,122.4,120.2,112.7,112.3,100.8,100.7,52.4,49.2$, $46.0,44.7,43.9,30.7,30.5,28.7,28.3,28.2,27.9,27.3,27.0$, ${ }_{20} 26.5,26.2,26.1,25.4,21.6,21.5,13.1,13.0$ ppm. ${ }^{195} \mathrm{Pt}\left\{{ }^{1} \mathrm{H}\right\}$ $\left(107.51 \mathrm{MHz}, \mathrm{CDCl}_{3}\right): \delta_{\mathrm{Pt}}-2788 \mathrm{ppm}$. HR-MS: calcd. 883.3001 for $\left[\mathrm{C}_{46} \mathrm{H}_{45} \mathrm{~N}_{2} \mathrm{O}_{4}{ }^{194} \mathrm{Pt}\right]^{+}$, found $\mathrm{m} / z=883.3010$. UV-vis $\left(\mathrm{CHCl}_{3}\right)$ : $\lambda_{\text {max }}\left(\varepsilon / \mathrm{dm}^{3} \mathrm{~mol}^{-1} \mathrm{~cm}^{-1}\right) 256$ (32100), 266 (39400), 278 (48200), 297 (25000), 314 (19900), 329(30300), 345 (38300), 361 25 (10600), $408(5330) \mathrm{nm}$. IR (thin film): $v_{\max } 1634(\mathrm{C}=\mathrm{O}), 1580$ $(\mathrm{C}=\mathrm{O}) \mathrm{cm}^{-1}$.

\section{Ackowledgements}

We thank the staff of the EPSRC Mass Spectrometry National Service (Swansea University) and the National Crystallographic ${ }_{30}$ Service at the University of Southampton. Access to the Cardiff University high performance computing facility "ARCCA" is gratefully acknowledged.

\section{Notes and references}

${ }^{a}$ School of Chemistry, Main Building, Cardiff University, Cardiff CF10 35 3AT. Fax: (+44) 029-20874030; Tel: (+44) 029-20879316; E-mail: popesj@cardiff.ac.uk; ${ }^{b}$ UK National Crystallographic Service, Chemistry, Faculty of Natural and Environmental Sciences, University of Southampton, Highfield, Southampton, SO17 1BJ, England.

$40 \dagger$ Electronic Supplementary Information (ESI) available:

a) A. Barbieri, B. Ventura, R. Ziessel, Coord. Chem. Rev., 2012, 256, 1732; b) X-Y. Wang, A. Del Guerzo, R.H. Schmehl, J. Photochem. Photobiol. C: Photochem. Rev., 2004, 5, 55; c) N.D. McClenaghan, Y. Leydet, B. Maubert, M.T. Indelli, S. Campagna, Coord. Chem. Rev., 2005, 249, 1336.

${ }^{2}$ O.S. Wenger, Coord. Chem. Rev., 2015, 282-283, 150.

${ }^{3}$ G.D. Scholes, Ann. Rev. Phys. Chem., 2003, 54, 57; A. Juris, V. Balzani, F. Barigelletti, P. Belser, A. von Zelewsky, Coord. Chem. Rev., 1988, 84, 85 .

${ }^{4}$ a) X. Zhang, T. Yang, S. Liu, Q. Zhao, W. Huang, in Chapter 'Transition-metal complexes for triplet-triplet annihilation-based energy up conversion' in Organometallics and Realted Molecules for Energy conversion. Springer 2015; b) W. Wu, D. Huang, X. Yi, J. Zhao, Dyes and Pigments, 2013, 96, 220.

${ }^{5}$ For example, P. Hammarstrom, B. Kalman, B-H. Jonsson, U. Carlsson, FEBS Lett., 1997, 420, 63; J. Duhamel, Langmuir, 2012, 28, 6527.
${ }^{6}$ A.J. Howarth, M.B. Majewski, M.O. Wolf, Coord. Chem. Rev., 2015, 282-283, 139.

${ }^{7}$ R.M. Edkins, K. Fucke, M.J.G. Peach, A.G. Crawford, T.B. Marder, A. Beeby, Inorg. Chem., 2013, 52, 9842.

${ }^{8}$ a) W.Y. Heng, J. Hu, J.H.K. Yip, Organometallics, 2007, 26, 6760; b) J. $\mathrm{Hu}$, J.H.K. Yip, D-L. Ma, K-Y. Wong, W-H. Chung, Organometallics, 2009, 28, 51; c) W.T. Wu, W.H. Wu, S.M. Ji, H.M. Guo, J. Zhao, Eur. J. Inorg. Chem., 2010, 4470.

${ }^{9}$ a) O. J. Stacey, S. J. A. Pope, $R S C A d v$., 2013, 3, 25550; b) A.J. Hallett, N. White, W. Wu, X. Cui, P.N. Horton, S.J. Coles, J. Zhao, S.J.A. Pope, Chem. Commun., 2012, 48, 10838.

${ }^{10}$ A.I. Baba, J.R. Shaw, J.A. Simon, R.P. Thummel, R.H. Schmehl, Coord. Chem. Rev., 1998, 171, 43

${ }^{11}$ For example, W.E. Ford, M.A.J. Rodgers, J. Phys. Chem., 1992, 96, 2917; G.J. Wilso, A. Launikonis, W.H.F. Sasse, A.W.-H. Mau, J. Phys. Chem. A, 1997, 101, 4860; J.A. Simon, S.L. Curry, R.H. Schmehl, T.R. Schatz, P. Piotrowiak, X. Jin, R.P. Thummel, J. Am Chem. Soc., 1997, 119, 11012; M. Hissler, A. Harriman, A. Khatyr, R. Ziessel, Chem. Eur. J., 1999, 5, 3366; D.S. Tyson, J. Bialecki, F.N. Castellano, Chem. Commun., 2000, 2355; J-E.S. Sohna, V. Carrier, F. Fages, E. Amouyal, Inorg. Chem., 2001, 40, 6061; A.F. Morales, G. Accorsi, N. Armaroli, F. Barigelletti, S.J.A. Pope, M.D. Ward, Inorg. Chem., 2002, 41, 6711; I.M.M de Carvalho, I. de S. Moreira, M.H. Gehlen, Inorg. Chem., 2003, 42, 1525; R. Lincoln, L. Kohler, S. Monro, H.M. Yin, M. Stephenson, R.F. Zong, A. Chouai, R. Dorsey, R. Hennigar, R.P. Thummel, S.A. McFarland, J. Am Chem. Soc., 2013, 135, 17161; M. Stephenson, C. Reichardt, M. Pinto, M. Wachtler, T. Sainuddin, G. Shi, H. Yin, S. Monro, E. Sampson, B. Dietzek, S.A. McFarland, J. Phys. Chem. A, 2014, 118, 10507.

12 a) S.A. Denisov, Y. Cudre, P. Verwilst, G. Jonusauskas, M. MarinSuarez, J.F. Fernandez-Sanchez, E. Baranoff, N.D. McClenghan, Inorg. Chem., 2014, 53, 2677; b) A.J. Howarth, D.L. Davies, F. Lelj, M.O. Wolf, B.O. Patrick, Inorg. Chem., 2014, 53, 11882.

13 a) I.E. Pomestchenko, C.R. Luman, M. Hissler, R. Ziessel, F.N Castellano, Inorg. Chem., 2003, 42, 1394; b) E.O. Danilov, I.E. Pomestchnko, S. Kinayyigit, P.L. Gentili, M. Hissler, R. Ziessel, F.N. Castellano, J. Phys. Chem. A, 2005, 109, 2465; c) H. Guo, S. Ji, W. Wu, W. Wu, J. Shao, J. Zhao, Analyst, 2010, 135, 2832.

${ }^{14}$ D.P. Lazzaro, P.E. Fanwick, D.R. McMillan, Inorg. Chem., 2012, 51, 10474.

15 J.P. Michalec, S.A. Bejune, D.R. McMillin, Inorg. Chem., 2000, 39, 2708.

${ }^{16}$ W. Wu, J. Sun, S. Ji, W. Wu, J. Zhao, H. Guo, Dalton Trans., 2011, 40, 11550.

${ }^{17}$ a) O.J. Stacey, J.A. Platts, S.J. Coles, P.N. Horton, S.J.A. Pope, Inorg Chem., 2015, 54, 6528; b) J.A. Lowe, O.J. Stacey, P.N. Horton, S.J. Coles, S.J.A. Pope, J. Organomet. Chem., 2016, 805, 87; c) O.J. Stacey, A.J. Amoroso, J.A. Platts, P.N. Horton, S.J. Coles, D. Lloyd, C.F. Williams, A.J. Hayes, J.J. Dunsford, S.J.A. Pope, Chem. Commun., 2015, 51, 12305.

${ }^{18}$ A. Juris, V. Balzani, P. Belser, P. von Zelewsky, Helv. Chim. Acta 1981, 64, 2175.

${ }^{19}$ For a recent article in which the effect of adding dispersion to DFT calculations is discussed, see: L. Castro, E. Kirillov, O. Miserque, A. Welle, L. Haspeslagh, J-F. Carpentier, L. Maron, ACS Catalysis, $2015,5,416$.

${ }^{20}$ B.D. Ward, S.R. Dubberley, L.H. Gade, P. Mountford, Inorg. Chem., 2003, 42, 4961

${ }^{21}$ J.Y. Cho, K.Y. Suponitsky, J. Li, T.V. Tirnofeeva, S. Barlow, S.R. Marder, J. Organomet. Chem., 2005, 690, 4090.

${ }^{22}$ N. Godbert, T. Pugliese, I. Aiello, A. Bellusci, A. Crispini, M. Ghedini, Eur. J. Inorg. Chem., 2007, 5105.

${ }^{23}$ B.M. Still, P.G.A. Kumar, J.R. Aldrich-Wright, W.S. Price, Chem. Soc. Rev., 2007, 36, 665.

${ }^{24}$ S. Alvarez, Dalton Trans., 2013, 42, 8617. 
${ }^{25}$ M. Frank, M. Nieger, F. Vogtle, P. Belser, A. von Zelewsky, L. de Cola, V. Balzani, F. Barigelletti, L. Flamigni, Inorg. Chim. Acta, 1996, 242, 281.

${ }^{26}$ D.F. Evans, J. Chem. Soc., 1957, 1351

${ }^{27}$ J.S. de Melo, A.J.F.N. Sobral, A.M.D.R. Gonsalves, H.D.Burrows, $J$. Photochem. Photobiol. A, 2005, 172, 151.

${ }^{28}$ S.J. Coles, P.A. Gale, Chem. Sci., 2012, 3, 683.

${ }^{29}$ CrystalClear-SM Expert 3.1 b27, 2013, Rigaku

${ }^{30}$ L. Palatinus, G. Chapuis, J. Appl. Cryst., 2007, 40, 786

${ }^{31}$ G.M. Sheldrick, Acta Cryst., 2015, C71, 3.

${ }^{32}$ M.J. Frisch, G.W. Trucks, H.B. Schlegel, G.E. Scuseria, M.A. Robb, J.R. Cheeseman, J.A. Montgomery Jr., T. Vreven, K.N. Kudin, J.C. Burant, J.M. Millam, S.S. Iyengar, J. Tomasi, V. Barone, B. Mennucci, M. Cossi, G. Scalmani, N. Rega, G.A. Petersson, H. Nakatsuji, M. Hada, M. Ehara, K. Toyota, R. Fukuda, J. Hasegawa, M. Ishida, T. Nakajima, Y. Honda, O. Kitao, H. Nakai, M. Klene, X. Li, J.E. Knox, H.P. Hratchian, J.B. Cross, V. Bakken, C. Adamo, J. Jaramillo, R. Gomperts, R.E. Stratmann, O. Yazyev, A.J. Austin, R. Cammi, C. Pomelli, J.W. Ochterski, P.Y. Ayala, K. Morokuma, G.A. Voth, P. Salvador, J.J. Dannenberg, V.G. Zakrzewski, S. Dapprich, A.D. Daniels, M.C. Strain, O. Farkas, D.K. Malick, A.D. Rabuck, K. Raghavachari, J.B. Foresman, J.V. Ortiz, Q. Cui, A.G. Baboul, S. Clifford, J. Cioslowski, B.B. Stefanov, G. Liu, A. Liashenko, P. Piskorz, I. Komaromi, R.L. Martin, D.J. Fox, T. Keith, M.A.AlLaham, C.Y. Peng, A. Nanayakkara, M. Challacombe, P.M.W. Gill, B. Johnson, W. Chen, M.W. Wong, C. Gonzalez, J.A. Pople, Gaussian 03, Revision E.01. Gaussian, Inc., Wallingford CT, 2004.

${ }^{33}$ a) A.D. Becke, J. Chem. Phys., 1993, 98, 5648; b) C. Lee, W. Yang, R.G. Parr, Phys. Rev. B, 1988, 37, 785; c) B. Miehlich, A. Savin, H. Stoll, H. Preuss, Chem. Phys. Lett., 1989, 157, 200.

${ }^{34}$ S. Grimme, J. Antony, S. Ehrlich, H. Krieg, J. Phys. Chem., 2010, 132, 154104.

${ }^{35}$ W.J. Hehre, R. Ditchfield, J.A. Pople, J. Chem. Phys., 1972, 56, 2257.

${ }^{36}$ J.D. Routledge, A.J. Hallett, J.A. Platts, P.N. Horton, S.J. Coles, S.J.A. Pope, Eur. J. Inorg. Chem., 2012, 4065. 